\title{
CONTAMINACIÓN POR PLOMO
}

\section{LEAD POLLUTION}

Carlos Gamero Esparza: Universidad Inca Garcilaso de la Vega (Perú). carlos.gamero@ozu.es

\section{CURRÍCULUM VITAE}

Reconocido Periodista peruano. Licenciado con Diploma de Honor en la Universidad Inca Garcilaso de la Vega.

\section{RESUMEN}

Este artículo es una readaptación del reportaje titulado "Humo y fábricas nos ahogan", publicado en el diario OJO de Lima el pasado año 2001. Viene a denunciar la contaminación por plomo existente en una localidad del país sudamericano. De un total de 82 muestras sanguíneas tomadas a escolares de entre 6 y 13 años de edad, 25 presentaron concentración de plomo sanguíneo entre 10,1 y $16,4 \mathrm{mg} / \mathrm{dl}$ (microgramos por decilitro de sangre). Los síntomas de los alumnos con niveles de plomo sanguíneo mayor a $10 \mathrm{mg} / \mathrm{dl}$ fueron cefalea, insomnio, fatiga, anorexia, tos crónica, cólicos abdominales y vómitos. El problema se agrava porque las partículas del mineral al descubierto son arrastradas por el viento en densas polvaredas que se introducen en las casas y se deposita en las calles, techos, cordeles de ropa, cabellos y piel de los pobladores y, por supuesto, en el organismo a través de la respiración. A pesar de las evidencias, los estudios realizados y la cada vez mayor cantidad de casos clínicos, sobre todo en la población infantil, esta situación todavía no ha sido encarada correctamente tanto por el sector público como por el sector privado. 


\section{PALABRAS CLAVE}

Plomo - Humo - Fábricas - Síntomas - Población infantil

\section{ABSTRACT}

This article is a readjustment of the report titled "Smoke and factories drown us," the newspaper published in Lima last EYE 2001. Comes to denouncing the existing lead contamination in a South American country town. Of a total of 82 blood samples of schoolchildren 6 to 13 years of age, 25 had blood lead levels between 10.1 and 16.4 mg / dl (micrograms per deciliter of blood). The symptoms of children with blood lead levels greater than $10 \mathrm{mg} / \mathrm{dl}$ were headache, insomnia, fatigue, anorexia, chronic cough, abdominal cramps and vomiting. The problem is compounded because the mineral particles are swept bare by wind in dense dust clouds that are introduced into the homes and deposited in the streets, roofs, strings of clothes, hair and skin of people and, of course, the body through breathing. Despite the evidence, studies and the growing number of clinical cases, especially in children, this situation has not yet been addressed properly by both the public and private sector.

\section{KEY WORDS}

Lead - Smoke - Factories - Symptoms - Child population

\section{ÍNDICE}

1. Introducción

2. En el Callao están peor

3. Plomo Sanguíneo

4. Malos aires 
5. Saturnismo: una epidemia silenciosa

5.1 ¡Cuidado con los niños!

5.2 ¿Cómo combatir el saturnismo?

6. En el Perú, este mal es sólo una "enfermedad laboral"

7. Geografía del mal

7.1 Plomo de más allá...

7.2 ... y el de más acá

8. Una historia larga como su tragedia

9. ¿Sabía usted qué...?

9.1 ... el plomo está en...

9.2 Ficha técnica del plomo como contaminante

10. Epílogo

10.1 Los niños del plomo

10.2 ¡Paren la contaminación por plomo!

10.3 El Callao, sólo un botón de muestra...

11. Recortes

11.1 Las empresas potencialmente más contaminantes del territorio español

11.2 Cormin modernizará depósito de imex Callao en seis meses

12. Anexo: Proyecto Eco Callao

13. Bibliografía

TEXTO:

\section{Introducción}

Los humos blancos, marrones, grises y negros se escurren día y noche de las instalaciones de la empresa recicladora de chatarra Mepsa, en El Agustino. La 
humareda se diluye con el aire que respiran miles de pobladores y, aparentemente, "no pasa nada". Esta es una de las tantas fábricas que varias décadas atrás se instalaron en una zona superpoblada. Desde hace un tiempo, los lugareños achacan a estos "malos humos" los mismos problemas de salud que aquejan a los millones de limeños que diariamente tienen que soportar las agresiones ambientales de industrias y vehículos motorizados. Sin embargo, las autoridades competentes ¿o incompetentes? todavía están en el limbo.

Cuando a comienzos del año 2000, la Prensa y la TV se hicieron eco del clamor de los vecinos del Agustino, los ejecutivos de Mepsa negaron que su actividad sea contaminante e informaron que habían invertido 890 mil dólares en la adquisición de un colector de polvos y en la ejecución del Programa de Adecuación al Medio Ambiente (PAMA). Cuando autoridades de salud y un fiscal inspeccionaron Mepsa, sus responsables dijeron que ésta se hallaba en mantenimiento y que los hornos se encontraban apagados. Y, aunque se comprobó el grado de saturación por polvos contaminantes, todo quedó como estaba.

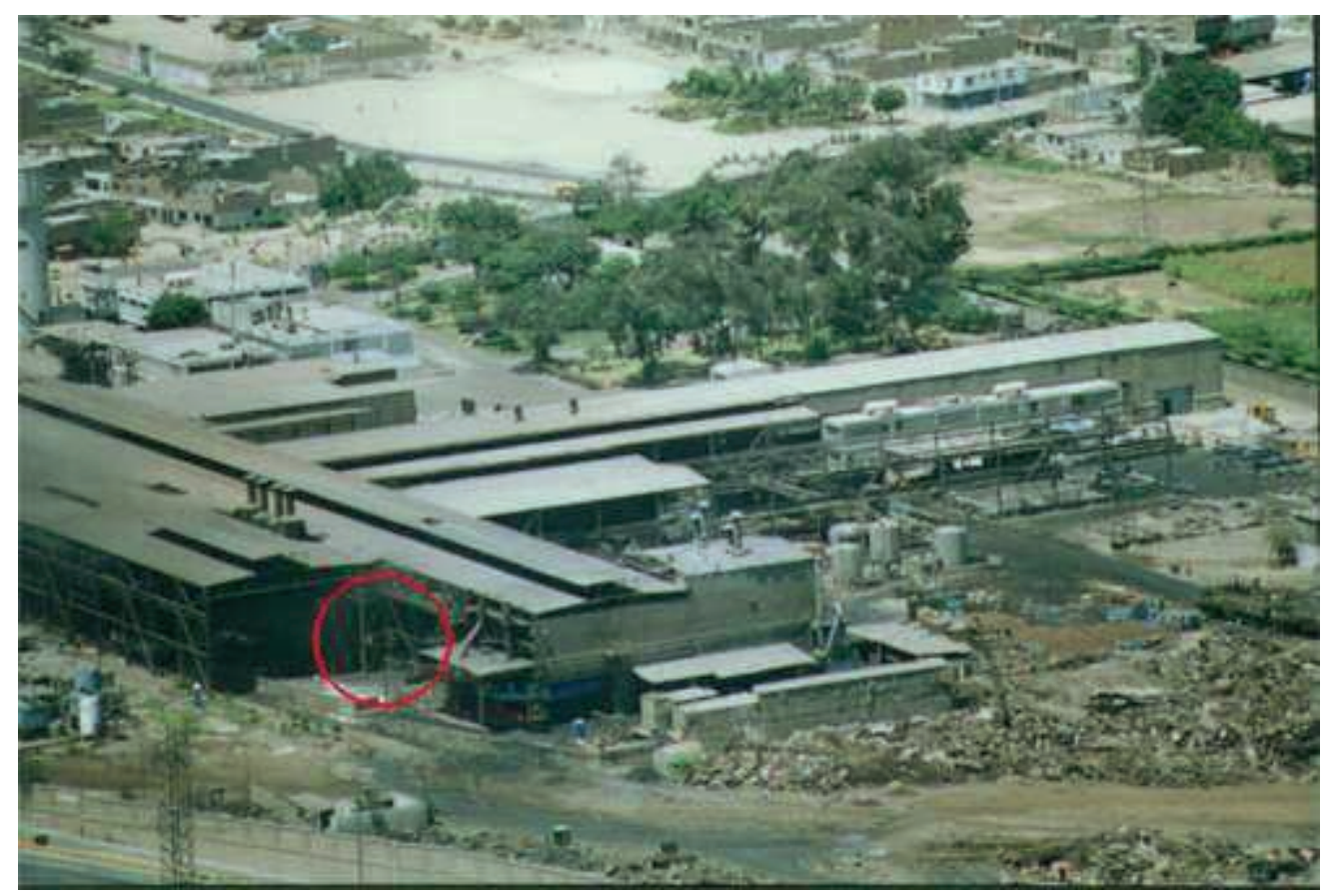


En el círculo rojo de la parte inferior de la imagen se puede apreciar como emana el humo tóxico de esta fundición de chatarra ubicada en plena zona urbana del Agustino. (Foto de Carolina Isabel Guerra).

Poco después, en noviembre de aquel año, un documento elaborado por el Centro de Control Toxicológico (CICOTOX) de la Facultad de Medicina Humana de la Universidad Mayor de San Marcos de Lima, dio cuenta de niños intoxicados por plomo en el Colegio Estatal \# 127 de El Agustino, muy cercano a la ferretera Mepsa. De un total de 82 muestras sanguíneas tomadas a escolares de entre 6 y 13 años de edad, 25 presentaron concentración de plomo sanguíneo entre 10,1 y 16,4 mg/dl (microgramos por decilitro de sangre). Los síntomas de los alumnos con niveles de plomo sanguíneo mayor a $10 \mathrm{mg} / \mathrm{dl}$ fueron cefalea, insomnio, fatiga, anorexia, tos crónica, cólicos abdominales y vómitos.

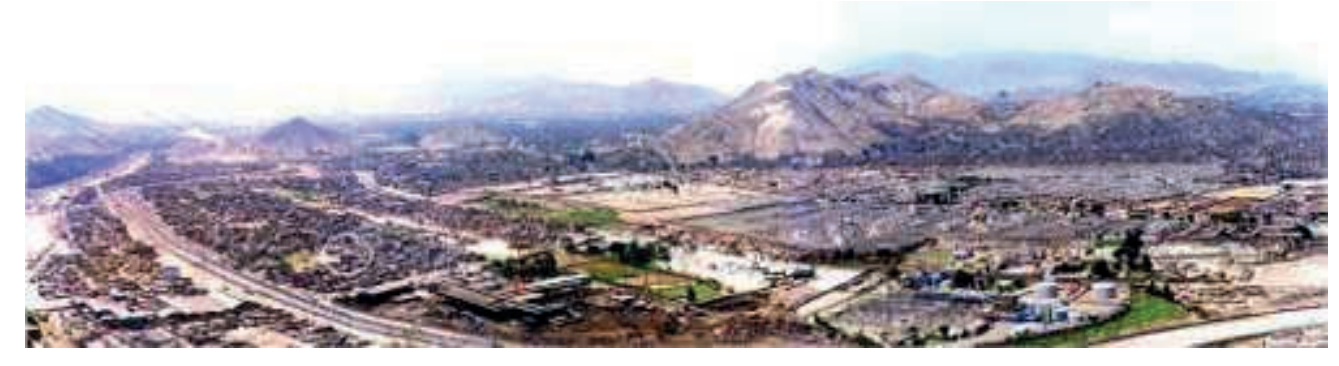

Impresionante vista de la zona de El Agustino con la chatarrera Mepsa (en el círculo blanco), rodeada de zonas pobladas. (Foto de Carolina Isabel Guerra)

A este estudio se sumó un informe de la Dirección General de Salud Ambiental (DIGESA), del Ministerio de Salud peruano, el cual determinó que pobladores de 10 asentamientos humanos de la margen izquierda del Río Rímac tienen problemas de salud relacionados con emanaciones de partículas procedentes del reciclaje de papel y cartón, y de la planta de cemento Unicom S.A., que funciona junto a Mepsa. 


\section{En el Callao están peor}

En el Colegio Nacional "María Reiche", en el Asentamiento Humano Puerto Nuevo, en la Provincia Constitucional del Callao, los niñitos ya las pintan rodeados de humo y piedras. Es que su plantel educativo más parece estar en una zona minera. Allí pululan los depósitos al aire libre de minerales, en su mayor parte plomo, zinc, estaño, manganeso, cobre, hierro, carbón mineral y otros, que son manipulados sin tomar medidas de seguridad contra la contaminación, a pesar de que hace varios años DIGESA realizó un estudio en los pueblos de Chacaritas, Puerto Nuevo, Frigorífico, Guardia Chalaca y Barrio Fiscal \# 3 (todos en la misma zona), donde viven unas 60 mil personas.

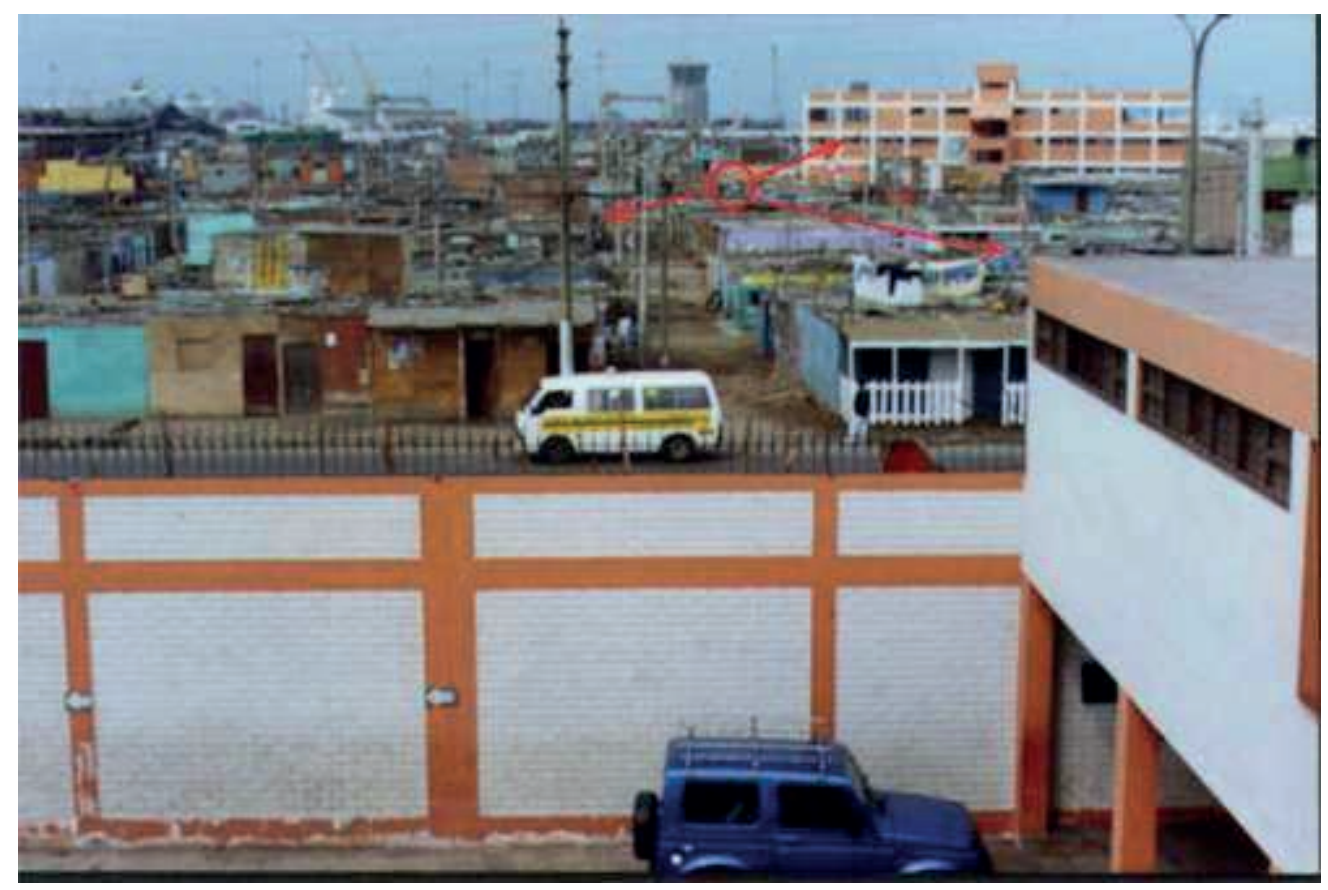

Vista parcial de Puerto Nuevo, en el Callao, con sus centros escolares (flechas) expuestos al plomo de los depósitos (al fondo). El edificio de ladrillos rojos, arriba a la derecha, es el colegio María Reche. (Foto de Carolina Isabel Guerra) 


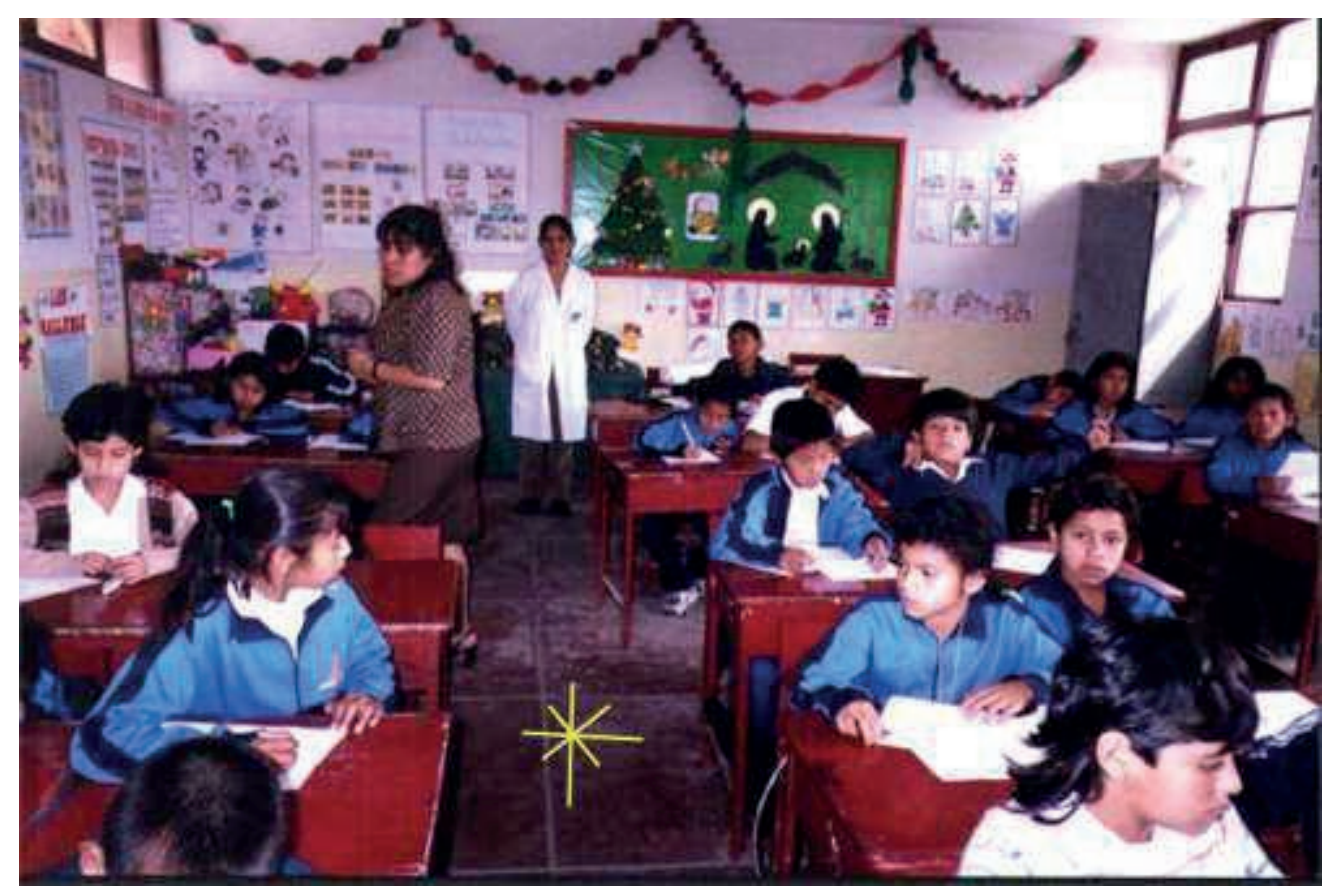

Salón de Clases del Centro Educativo María Reiche, en Puerto Nuevo, Callao. En esta aula había muchos pequeños con excesiva cantidad de plomo en la sangre. (Foto de Carolina Isabel Guerra)

El problema se agrava porque las partículas del mineral al descubierto son arrastradas por el viento en densas polvaredas que se introducen en las casas y se deposita en las calles, techos, cordeles de ropa, cabellos y piel de los pobladores y, por supuesto, en el organismo a través de la respiración. Aquí DIGESA registró índices de entre 50 y $60 \mathrm{mg} / \mathrm{dl}$ de plomo en la sangre de niños en edad escolar, cuando el valor máximo en niños menores de 12 años según la Organización Mundial de la Salud (OMS), no debe pasar los $10 \mathrm{mg} / \mathrm{dl}$. 


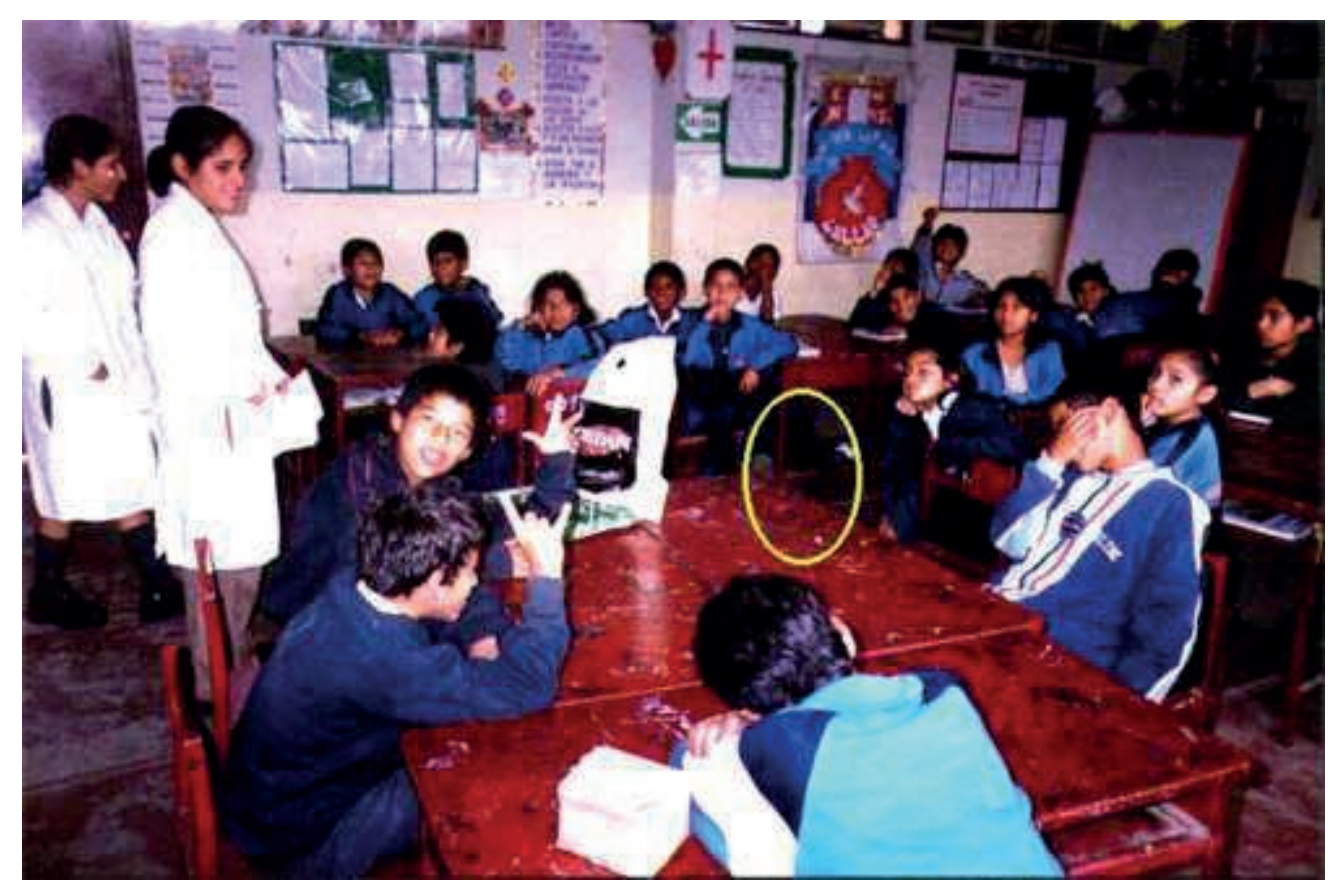

En esta aula del colegio María Reiche, en Puerto Nuevo, Callao, se encontró residuos de plomo en el piso (ver círculo amarillo). (Foto de Carolina Isabel Guerra)

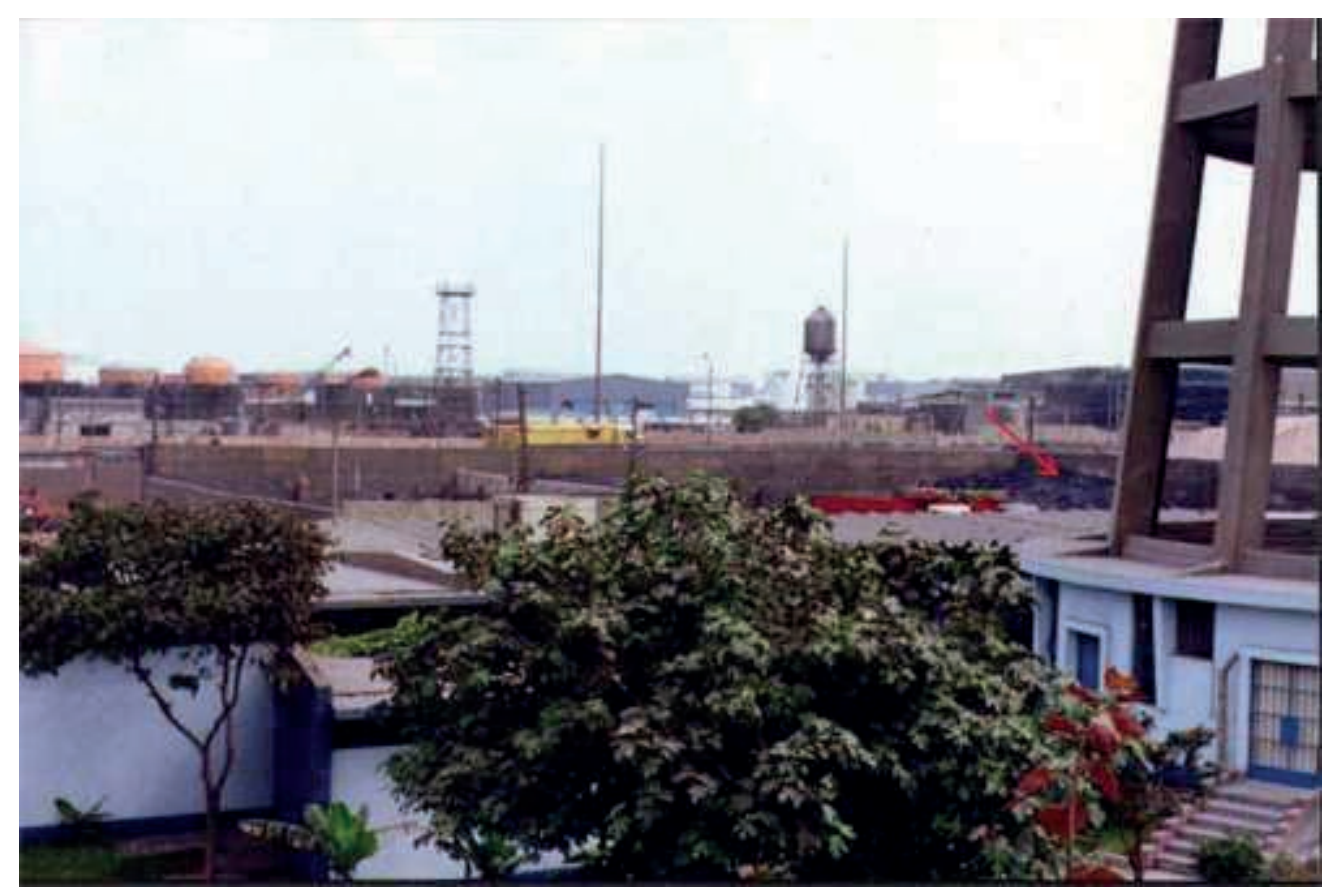

Las flechas señalan un cerro de plomo en estos depósitos cercanos al colegio María Reiche, en Puerto Nuevo, Callao. (Fotos de Carolina Isabel Guerra) 


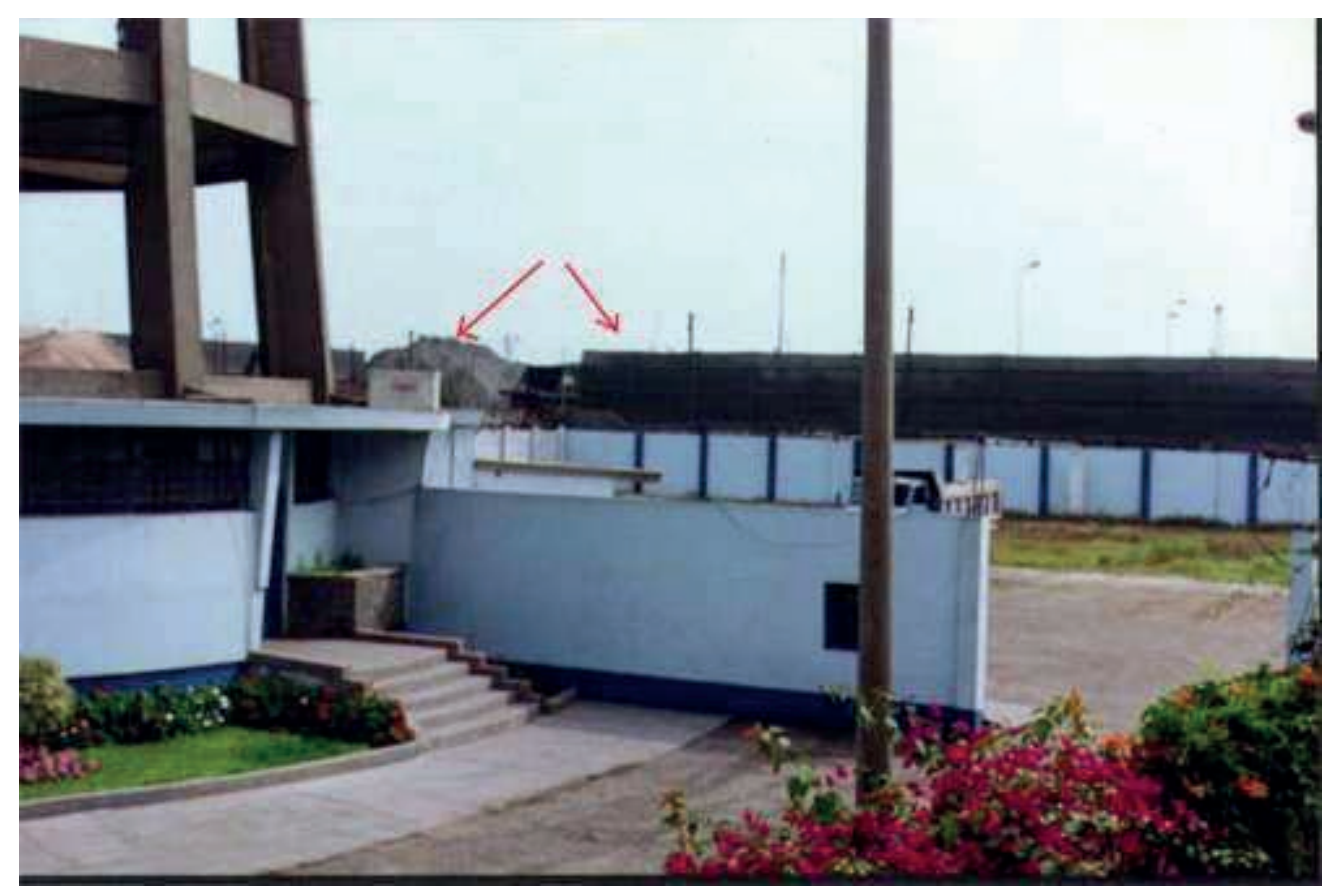

Es indudable que ningún barrio chalaco tiene tantos depósitos de plomo al aire libre, como Puerto Nuevo. Las flechas indican donde se encuentra el mineral. (Foto de Carolina Isabel Guerra)

\section{Plomo Sanguíneo}

Fuera de Lima también parece llover plomo... sobre plomo. En mayo de 1997, la Organización Panamericana de la Salud, OPS, publicó un estudio que reveló la existencia de plomo sanguíneo en los habitantes de cuatro ciudades peruanas. Entre 1994 y 1995, los investigadores de la OPS, Augusto Ramírez, Juan Paucar Cam y José M. Medina, estudiaron muestras sanguíneas de 180 hombres y 180 mujeres sin exposición laboral al plomo y procedentes de Lima, Huancayo, La Oroya y Yaupi.

Se utilizó el método de la absorción atómica para medir el plomo sanguíneo, con la ayuda de un espectrofotómetro Perkin Elmer 603 sin horno de grafito. Así se constató concentraciones de plomo en la sangre de 269 casos, que tenían 63 microgramos por litro, en Lima; 224 casos, con 47 microgramos por litro, en Huancayo; 348 casos, con 
40 microgramos por litro, en La Oroya; y otros 140 casos, con 40 microgramos por litro, en Yaupi. La conclusión fue que las concentraciones de plomo sanguíneo en los habitantes de estas ciudades guardaban relación con el grado de industrialización y la densidad demográfica de cada localidad.

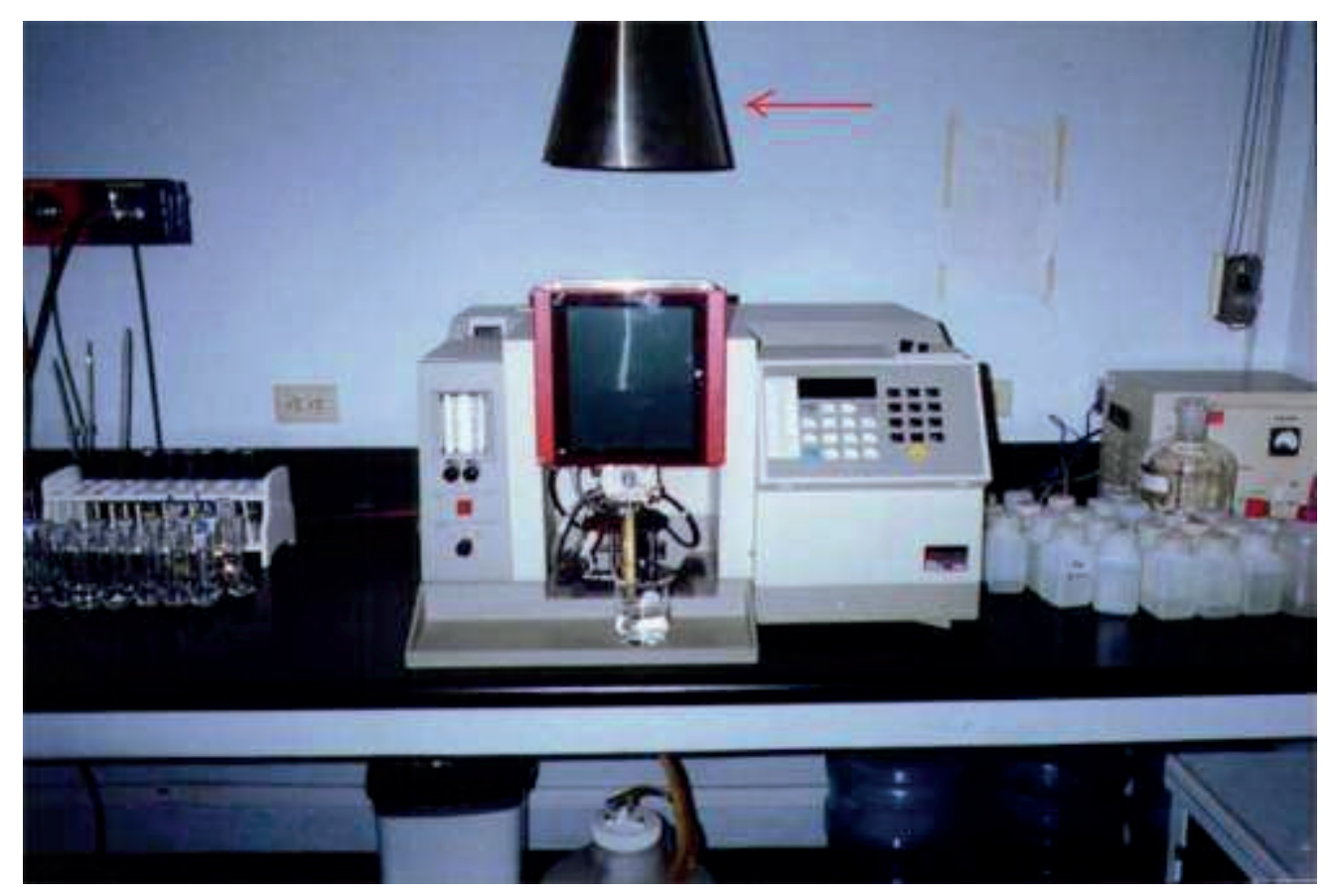

El espectrofotómetro de DIGESA, un aparato capaz de detectar elementos tóxicos ocultos al ojo humano. (Foto de Carolina Isabel Guerra)

\section{Malos aires}

Uno de los factores que más contribuyen en la contaminación ambiental de Lima es el clima. José Silva Cotrina, director de Medio Ambiente del Senamhi (Servicio Nacional de Meteorología e Hidrografía), señaló hace poco que el nivel de contaminantes sólidos, sedimentados, aquellos que caen en forma de polvo, llega en los sectores norte y este capitalinos a 35 toneladas por kilómetro cuadrado y mes, "cuando el límite máximo admisible recomendado por la OMS es de sólo 5 toneladas", es decir, siete veces más de lo permitido. 


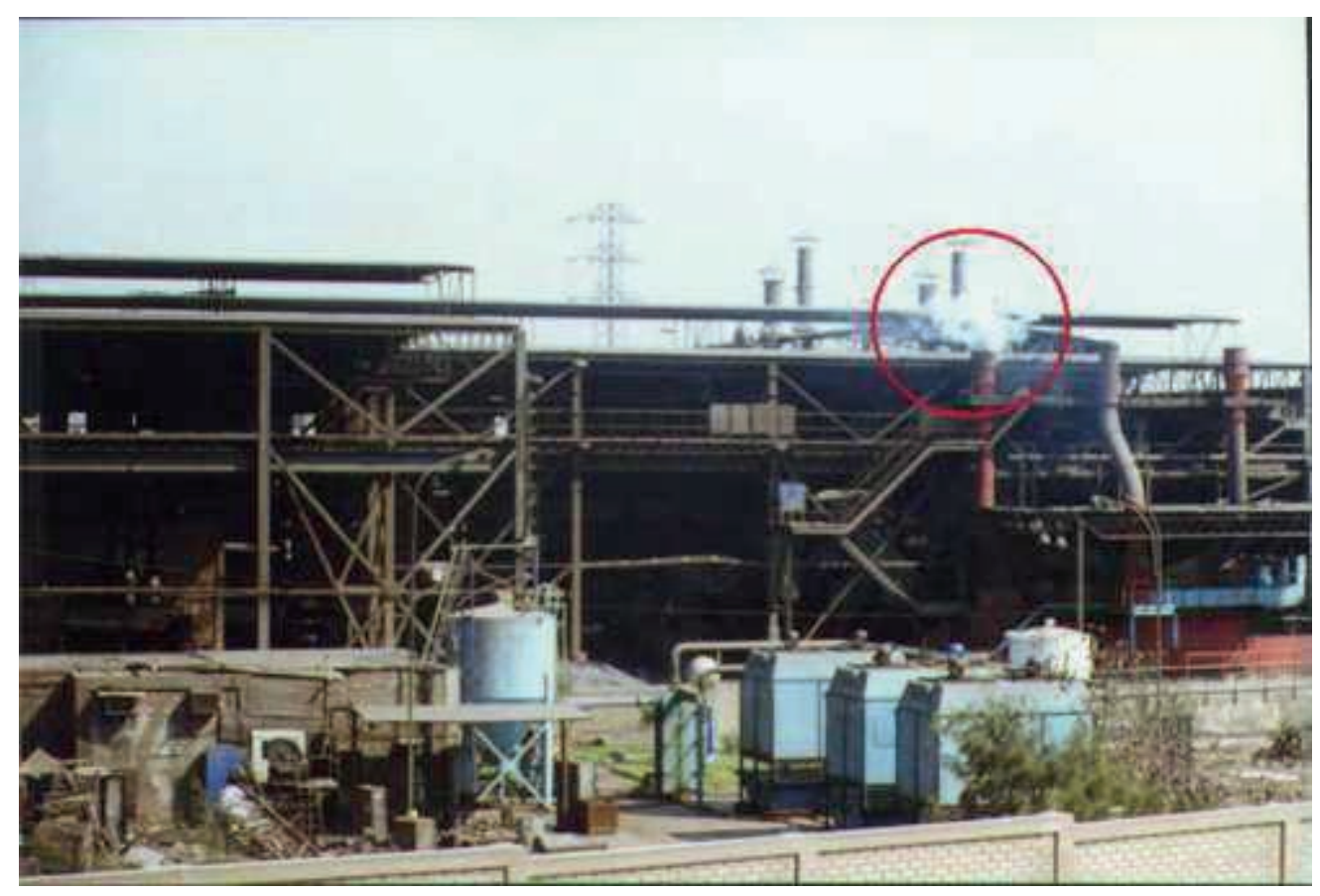

En la esquina de las avenidas Plácido Domingo y Evitamiento, en el Cercado de Lima, el humo de esta fundición de chatarra sale día y noche. (Foto de Carolina Isabel Guerra)

Según Silva, otras ciudades latinoamericanas con similar problema, como México DF, Santiago de Chile y Sao Paulo, tienen un sistema establecido de estándares de calidad del aire que permiten su control y mitigación. Lima no lo tiene.

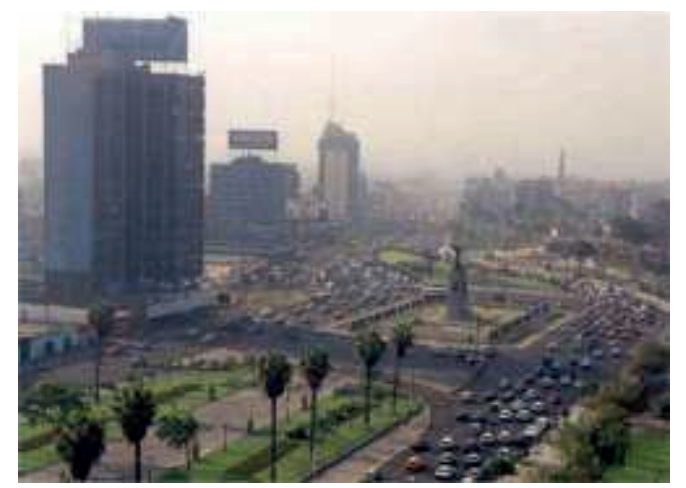

La céntrica plaza Grau de Lima, una de las más congestionadas de la ciudad.

Imagen obtenida de www.worldcityphotos.org/P/PER-

Limawskudududu1.jpg

Al estar ubicada en la costa, las brisas marinas ingresan y "arrastran toda la contaminación que se genera en Lima hacia los conos norte y este de la capital, que 
son las zonas más contaminadas", indicó. Precisamente, el nivel de contaminación registrado en estos sectores está en estrecha relación con los contaminantes sólidos en suspensión que "son los más peligrosos", ya que por su tamaño y peso ligero no sedimentan, se mantienen en el aire y se convierten en inhalables.

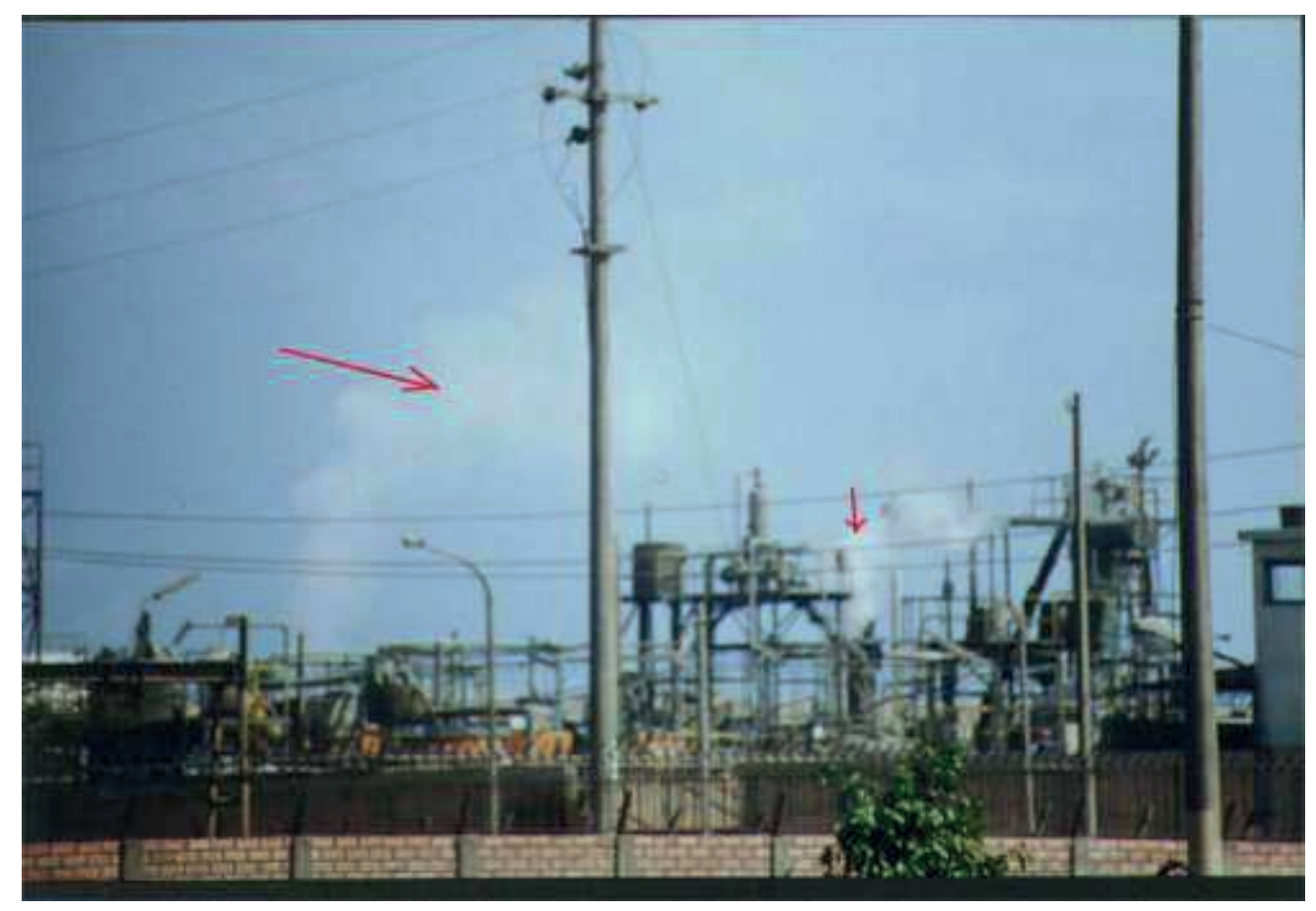

Esta fábrica echa humo a diestra y siniestra en la carretera a Ventanilla, sur del Callao, ¿quién la controla? (Foto de Carolina Isabel Guerra)

Para solucionar esta dramática situación, el experto recomendó la eliminación de las refinerías y fundiciones ubicadas dentro de la zona urbana, como sucedió en la ciudad de México DF, donde fueron cerradas. También urgió mejorar el obsoleto parque automotor limeño y la calidad de los combustibles de las 700.000 unidades que circulan por nuestras calles, pues un 65 al 90 por ciento del plomo incorporado en el organismo proviene de la combustión de la gasolina. 


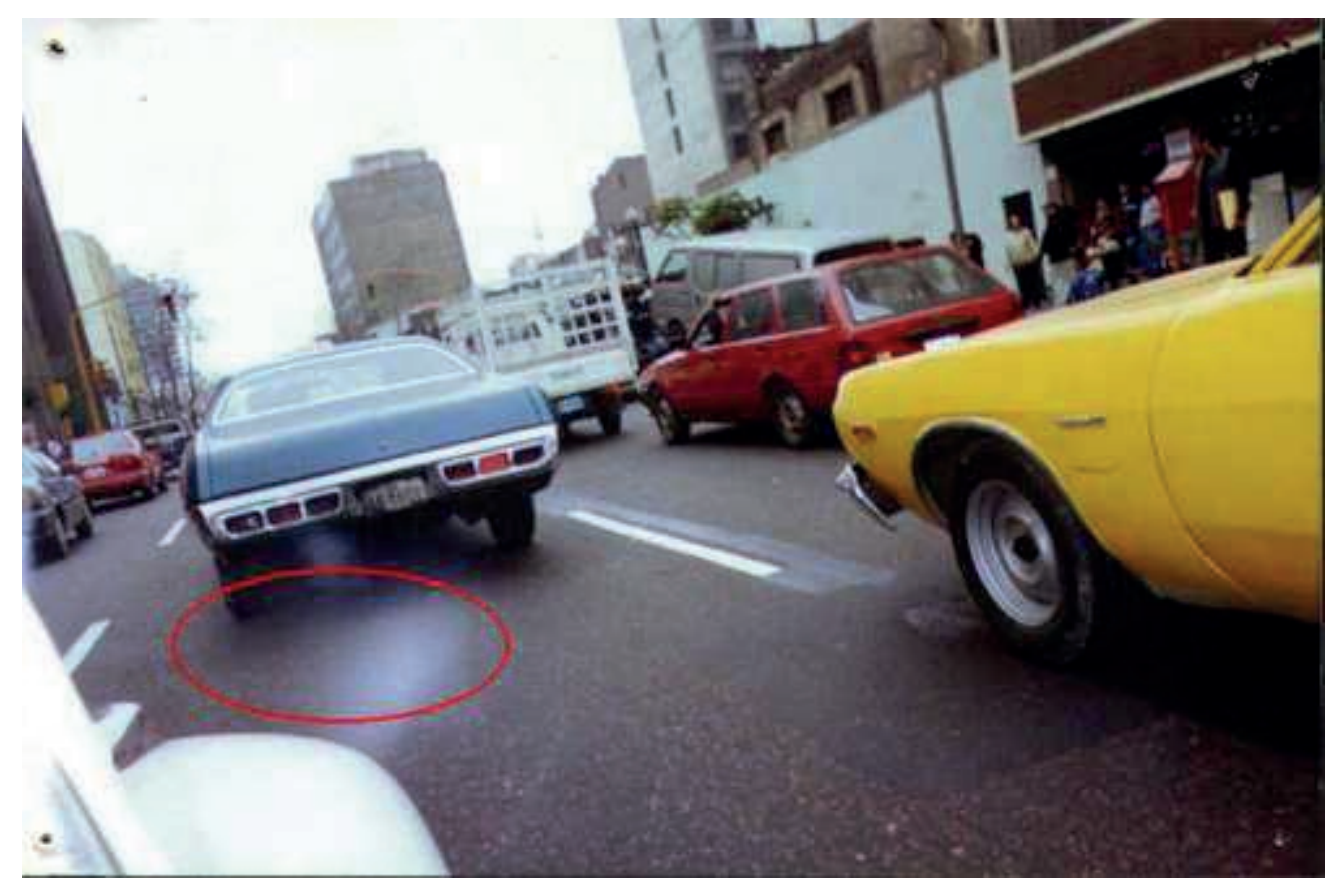

Este viejo automóvil es uno de los miles que a diario expulsan, entre otros productos, monóxido de carbono en Lima; el humo venenoso es producto de la combustión de una gasolina con plomo. (Foto de Carolina Isabel Guerra)

\section{Saturnismo: una epidemia silenciosa}

Su nombre viene del "color de Saturno", el gris. En algunos casos, la acumulación excesiva de plomo en la sangre produce tal efecto en el tinte de la piel de quien está afectado por este mal, también llamado "plumbosis" o "lengua negra", una cruel enfermedad que ahora está causando estragos en toda Latinoamérica.

\section{1 ¡Cuidado con los niños!}

Los más pequeños son sus principales víctimas. Las investigaciones han demostrado que los huesos y los tejidos blandos de los niños (cerebro, riñones e hígado), aún en proceso de desarrollo, absorben un 50\% del plomo, mientras que la tasa de absorción 
en los adultos es de un 20\%. En medio ambientes como el de Lima, la amenaza de ingestión o inhalación de este metal blando tóxico es latente.

Entre los síntomas que se presentan como resultado del envenenamiento por plomo, se pueden mencionar agudos dolores de cabeza, náuseas, hiper-irritabilidad, pérdida del apetito y debilitamiento general. Además de causar anemia, lesiones renales y daños en el sistema nervioso central, el saturnismo merma también el desempeño físico e intelectual del enfermo.

En los niños, los daños cerebrales pueden ser más severos debido a que el plomo afecta el aprendizaje. Asimismo, al acumularse lentamente en los huesos, el metal puede impedir el crecimiento normal de éstos, generando a veces hipertrofia o enanismo. En niveles muy altos puede causar ataques epilépticos, estado de coma e incluso la muerte.

Por otro lado, unos estudios realizados por el doctor Ramón Cendejas Ramírez, de la Facultad de Estudios Superiores de Cuatitlán, México, han demostrado que altas concentraciones de plomo podrían también provocar alteraciones en el organismo de la mujer embarazada y heredarlas sus hijos, que nacerían con acefalia.

\section{2 ¿Cómo combatir el saturnismo?}

Una vez detectada la existencia de plomo en la sangre, puede solucionarse con medidas higiénicas y dietéticas que reduzcan cualquier posibilidad de consumo de plomo, y así contrarrestar el ya existente en el torrente sanguíneo, sobre todo con alimentos ricos en hierro y calcioNOTA 1. En casos severos puede ser tratado con quelantes, compuestos que se ligan a los iones del metal formando complejos estables, que son excretados del organismo por la orina. 
Kiwicha

Es un grano andrio que tiene un oromedio de rave de proteiras: Generalmente se consume tostado o an haricas Se usa on sopes en 60 . cou fratismoras, turtones y panquequeet y en betidas calientes.

\section{Quinua}

Este estupendo grano asorta conno promedio $12.5 \%$ proteinas fir misy verate y se presta pea preparar inpan guses, retrescos y postres tia cocina novsendive lo emples en vir

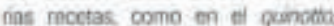
suerte die risotto de peruana estipe [mbs informacien en el fasciavio 19].

\section{Cañihua}

Es un grano miy pequeno que se consurre principalinerte iosdado o molda. Del la canthan se hece ef cah) hiace hanne can la que se preperan refiescos manmoras y bocades Uns cucharadta de cahihieco en ts lectre der desayuno es buena atterna. swa para mperar ef dia

\begin{abstract}
Alimentos andinos peruanos recomendados para prevenir y combatir la plumbosis o saturnismo, por su contenido en minerales y proteínas. (Foto de Carolina Isabel Guerra)
\end{abstract}

\section{Un científico de la Universidad de Pittsburg advierte que el plomo puede crear delincuentes}

En el marco de la Conferencia Conjunta de la Academia Americana de Pediatría, que tuvo lugar en mayo del año 2001, el investigador de la Universidad de Pittsburg, EEUU, Herbert Needleman, presentó un estudio basado en un grupo de 417 norteamericanos, que demostraría la influencia del plomo en las conductas antisociales de niños y adultos.

Según esta investigación, un niño que vive cerca de autopistas o calles con mucha circulación se expone a respirar en forma crónica grandes cantidades de plomo, si la gasolina que utilizan los vehículos contiene este metal. Además, un menor de edad que comienza a raspar la pintura de su dormitorio, si ésta contiene plomo, puede estar intoxicándose sin darse cuenta. Un chico que come de una lata de conservas abollada puede estar incorporando a su organismo un veneno de acción lenta pero letal: el plomo. 


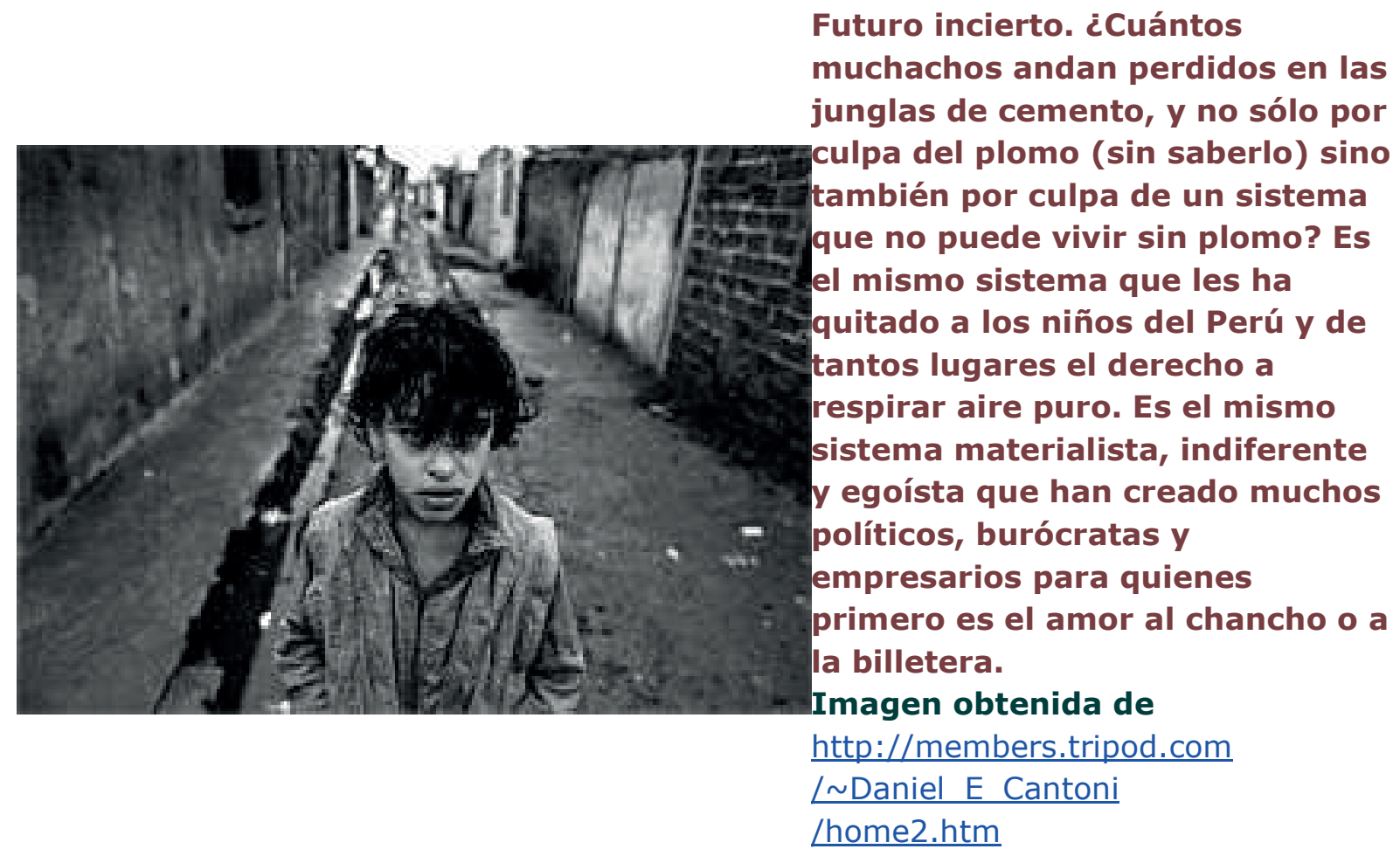

Pero al margen de todas estas situaciones, que son fuente de contaminación y daño para la salud, parece sumarse ahora otro peligro sobre quienes de manera voluntaria o involuntaria se exponen al plomo, en especial los más pequeños: este metal también tendría mucho que ver con el desarrollo de una personalidad agresiva y ansiosa, que puede llevar más tarde a la delincuencia criminal.

Needleman comparó los niveles de plomo en jóvenes sin antecedentes y en menores de edad que habían sido condenados por un juez. Dentro de los varones se vio que los convictos tenían casi el doble de probabilidades de presentar altos niveles de plomo en los huesos y que entre el 11 y el $37 \%$ de estos casos se relacionaba con una exposición temprana a este metal. Según el investigador, la exposición al plomo puede ser una de las causas de conducta criminal más sencillas de prevenir.

\section{Avalancha de evidencias}

"Estos resultados confirman el estudio previo de Needleman, que demostró una asociación entre conductas delictivas de adolescentes y niveles de plomo en huesos, que a su vez refleja la historia de exposiciones a este producto en los primeros años de la vida", comenta Andrei N. Tchernitchin, director del laboratorio de Patología Ambiental del Instituto de Ciencias Biomédicas, en Santiago de Chile. Hace ya ocho años que el doctor Tchernitchin y sus colegas propusieron un efecto del plomo, desconocido por ese entonces: la mayor tendencia a drogas de abuso y estimulantes, lo cual se ha ido demostrando progresivamente a través de estudios como el desarrollado por Needleman.

"El plomo causa en niños de corta edad un comportamiento hiperactivo, que va a desarrollar una personalidad agresiva, la cual tiene la tendencia de promover acciones antisociales ", señaló Tchernitchin. 


\section{En el Perú, este mal es sólo una "enfermedad laboral"}

A pesar de que el saturnismo existe y pasa factura, pocos parecen darse por enterados, pues, que sepamos, al menos en el Perú, las autoridades sanitarias le dan poca importancia. Aún así, el mal está allí y ha sido denunciado por numerosas organizaciones ecologistas, que son prácticamente las únicas que andan preocupadas por el problema. Según cuenta la investigadora Carolina Isabel Guerra Cáceres en su notable trabajo "Plomo... Peligro Inminente", en el Perú, un gran país minero que ocupa el sexto lugar en la producción mundial de plomo, los antecedentes de intoxicación plúmbica se refieren generalmente al ámbito ocupacional, especialmente el minero. Aquí existe, a nivel del Ministerio de Salud, una entidad encargada del estudio, la reglamentación y control de las enfermedades laborales: el Instituto de Salud Ocupacional del Perú del Ministerio de Salud.

Pero el problema no es sólo ocupacional... también la población no relacionada con la minería o la industria pesada la sufre en carne propia por culpa del plomo y otras sustancias tóxicas que enrarecen el medioambiente, y esto es precisamente lo que no parece entrar en la cabeza de las autoridades.

Hace poco, una comunidad de una provincia minera presentó una denuncia ante los tribunales contra la Compañía Southern Corporation, una de las mayores explotadoras de plomo en el país, por los graves efectos de la contaminación entre los pobladores de las zonas cercanas a los asentamientos mineros de la provincia de Ilo, en el departamento de Moquegua, unos 1000 kilómetros al sur de Lima. 


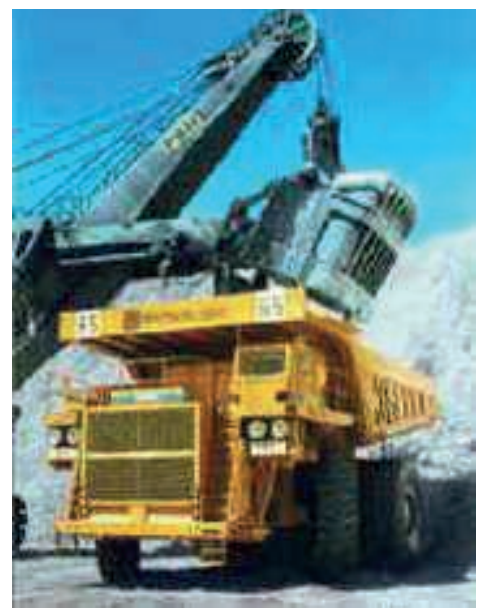

La actividad extractora de plomo de la empresa Southern Perú Corporation, en la mina de tajo abierto de Toquepala (Moquegua), ha causado muchos problemas en las poblaciones vecinas... pero hasta ahora las autoridades no entienden que el problema de la contaminación plúmbica no es solo un asunto "laboral". Imagen obtenida de http:/ / www.plades.org.pe/vigilia/southernilo.html

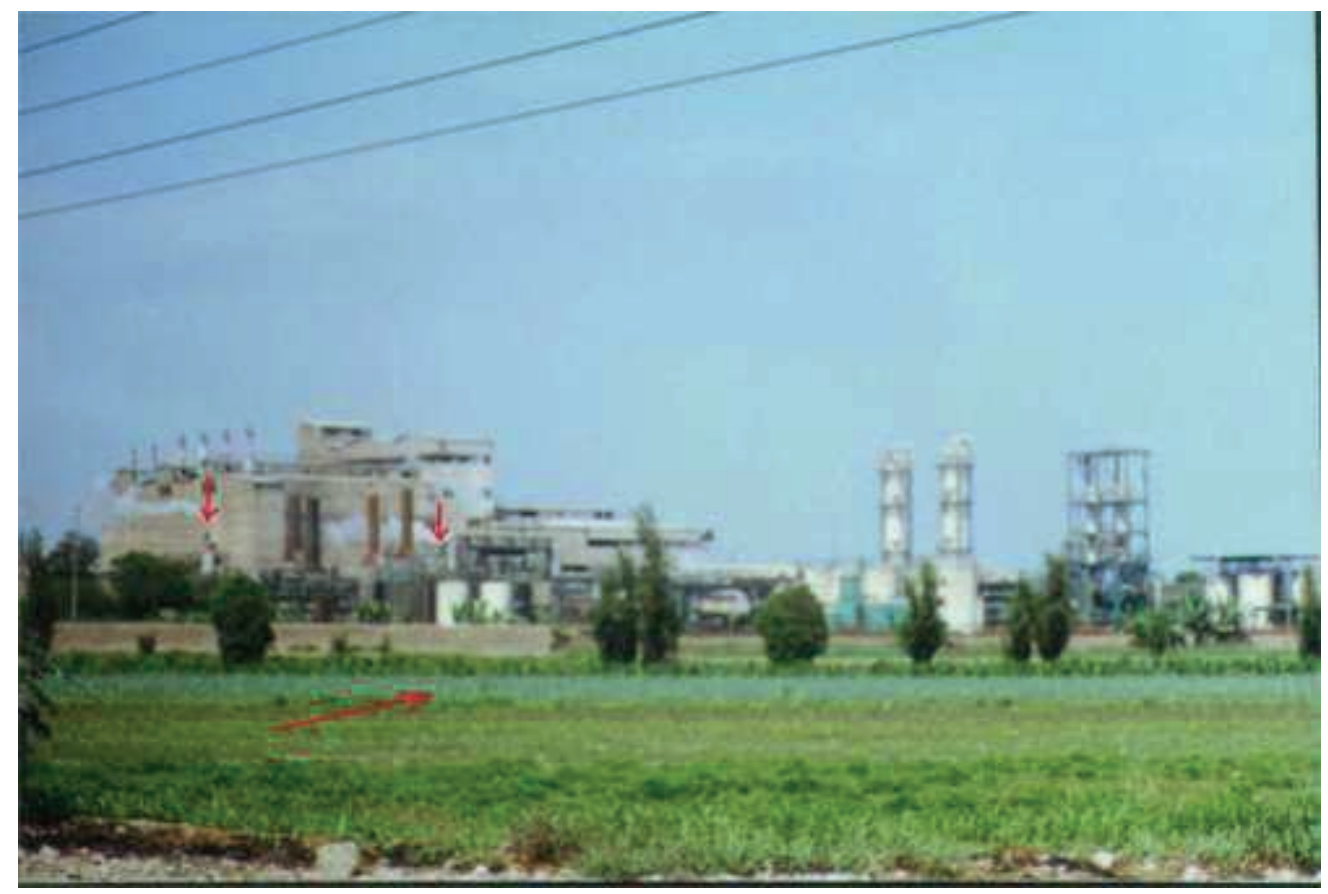

Las flechas señalan los humos tóxicos que brotan de esta chatarrera de la zona de El

Agustino, levantada junto a una tierra de cultivo. (Foto de Carolina Isabel Guerra) 
Por ello, Carolina Isabel Guerra ha estado tratando de demostrar que la población más vulnerable a la contaminación no es necesariamente la ocupacional, "sino más bien la población civil urbana; y especialmente los niños de estas poblaciones, donde el desconocimiento sobre el mal, sus fuentes, síntomas y cuidados, así como la precariedad de las condiciones de salubridad son los peores enemigos", explica la autora.

Y uno de los argumentos que se esgrimen para no tomar en cuenta este grave problema en el ámbito poblacional es el hecho de que Lima y Callao no son consideradas zonas mineras, a pesar de haberlas en las cercanías y contar con fundiciones y refinerías en plena zona urbana. Sin embargo, esta es una urbe que concentra los mayores índices de contaminación, pues, como dice Carolina Isabel Guerra, "el centralismo y un débil sistema de reglamentación y control en materia de límites permisibles de emisiones contaminantes, así como la falta de un sistema de información eficiente que permita ejercer este control en todos los sectores", ha hecho que los limeños y los no tan limeños (que esta es una urbe de inmigrantes de acá y de más allá) prácticamente estén "nadando" en aire viciado, saturado de plomo y otras sustancias tóxicas. 


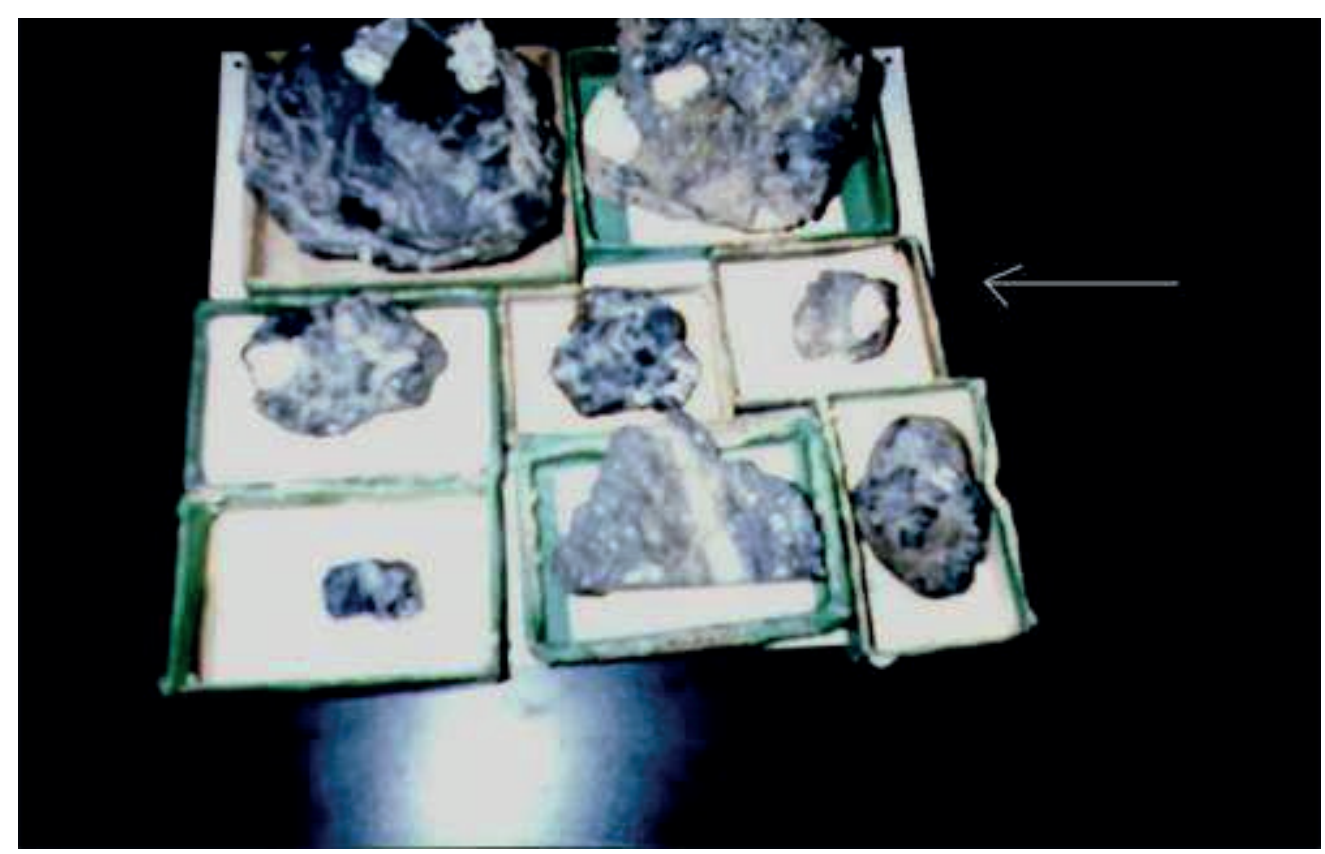

En el centro de Lima se encontró esta galena con alta concentración de plomo (obsérvese el color). (Foto de Carolina Isabel Guerra)

Las emanaciones tóxicas industriales son una de las mayores fuentes de contaminación. Entre éstas cabría citar las fábricas que utilizan plomo como insumo, recicladoras de chatarra que funcionan a vista y paciencia de las autoridades y cuyas plantas están ubicadas en plena zona urbana, incluso cerca de colegios y hospitales. Otra fuente son los miles de autos, camiones, microbuses, etc., que pululan caóticamente por calles y avenidas que no se dan abasto para tanto tráfico. El 60\% del parque automotor utiliza gasolinas de 84 y 95 octanos, las que contienen plomo, cuya erradicación recién ha sido programada para el año 2004. 


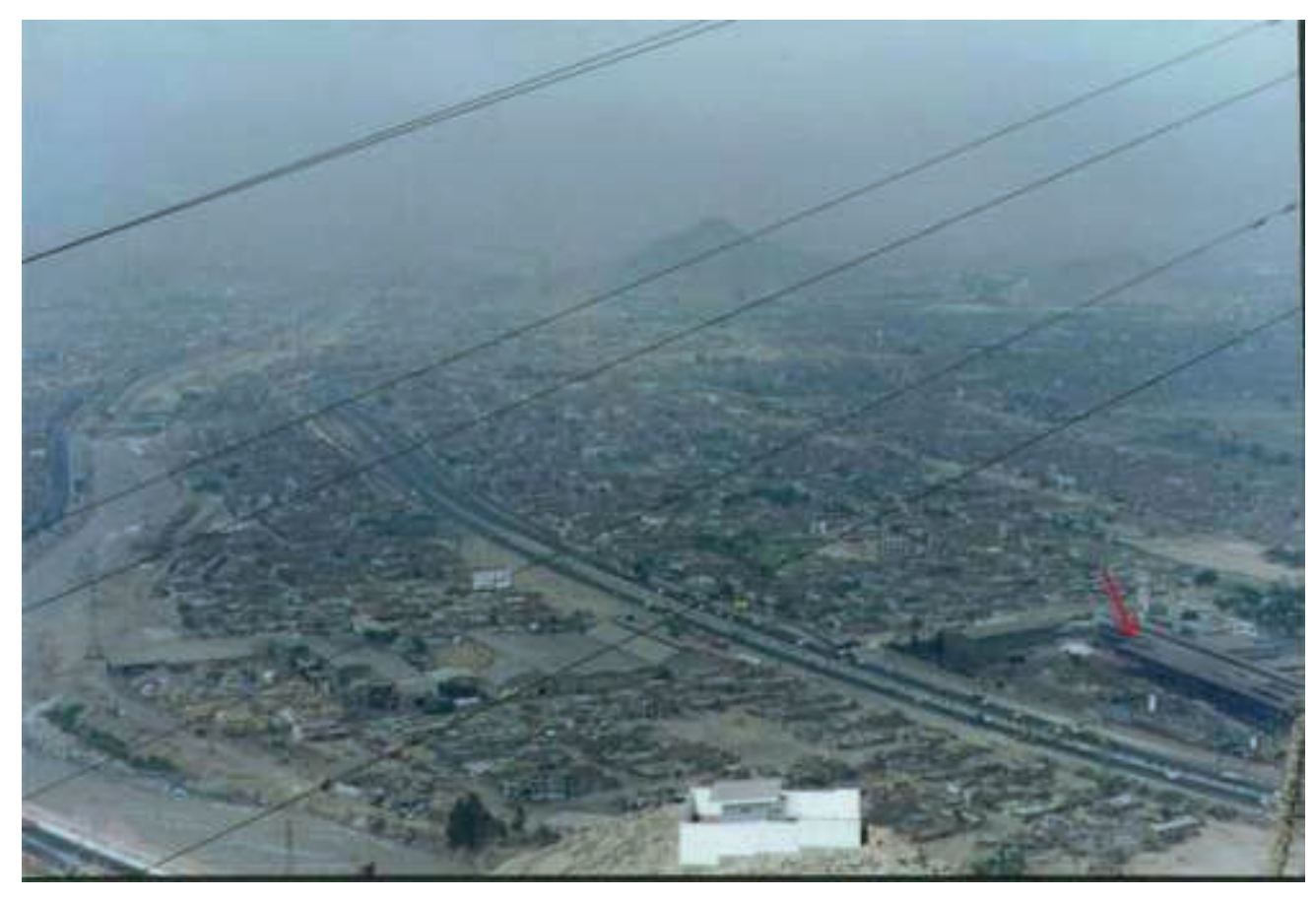

La zona de la Vía de Evitamiento, junto al río Rímac, no está bajo una niebla londinense sino bajo el "smog" de las chimeneas. Las flechas en rojo señalan fuentes contaminantes. (Foto de Carolina Isabel Guerra)

Otro grave problema es el traslado y acumulación de mineral desde las zonas mineras hasta los depósitos ubicados en el Puerto del Callao para su embarque en los grandes muelles. Esta situación ha provocado un verdadero desastre ecológico y de salud pública, pues estos depósitos, como se ha señalado, están levantados al aire libre sin la menor protección. Además, la operación de transporte del mineral hasta el Callao se realiza en camiones con la tolva desprotegida o en el Ferrocarril Central, de cuyos vagones a cielo descubierto se suele desperdigar el mineral a su paso por zonas pobladas asentadas a lo largo de la vía férrea. 


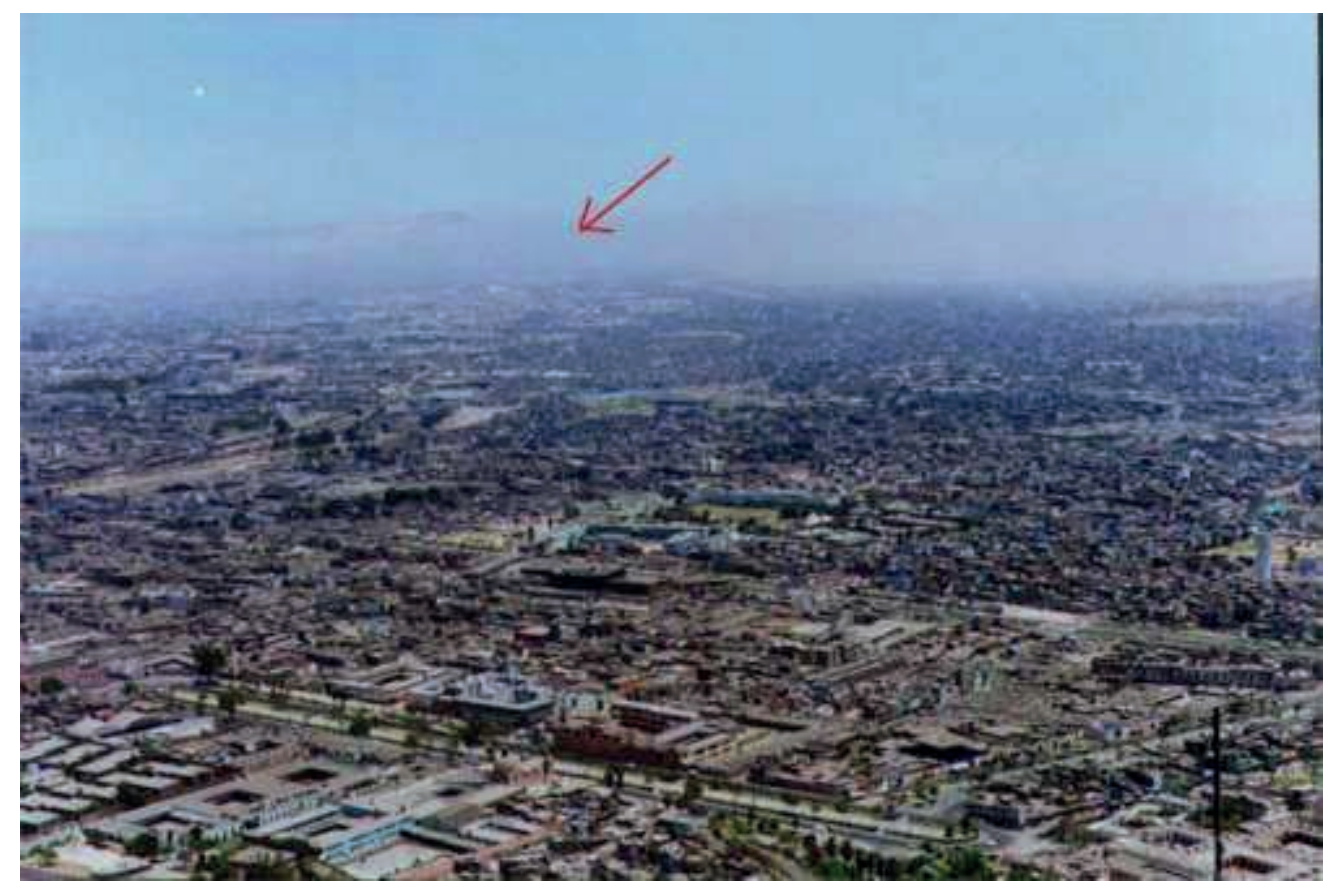

Una densa capa de humo (flecha) cubre un vasto sector del este de Lima.

Foto de Carolina Isabel Guerra

\section{Geografía del mal}

\subsection{Plomo de más allá...}

Fuera del Perú, se han detectado infinidad de casos de contaminación por plomo y sus terribles secuelas en niños y adultos de todo el mundo, aunque en otras latitudes también parece repetirse el caso peruano... la plumbosis o saturnismo sólo es reconocido en muchos lugares como un mal de ámbitos laborales, y esto parece ser la peor enfermedad. En México, se ha detectado que las emisiones anuales de contaminantes superan las 16 millones de toneladas, de las cuales el $65 \%$ es de origen vehicular. En el norte y centro de este país, varias fundiciones fueron denunciadas debido a que estaban cerca de escuelas, donde miles de niños comenzaron a sufrir síntomas de intoxicación por plomo. Sin embargo, a pesar de la indignación pública, 
el caso fue cerrado por considerarse que los implicados no estaban dentro de zona minera.

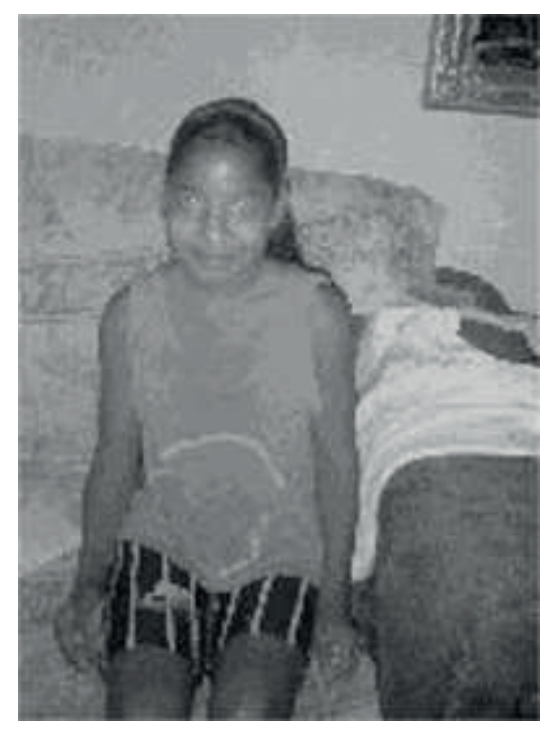

Una de las niñas afectadas por plomo en Torreón, en las colonias aledañas a Peñoles, zona metropolitana de México DF, donde en 1999 se detectaron 1800 casos de saturnismo. Foto archivo. Diario "La Crónica de Hoy", Saltillo, México, 18 de mayo de 1999. Imagen obtenida de www.webcom.com.mx/cronica/1999/may/18 /med03.html

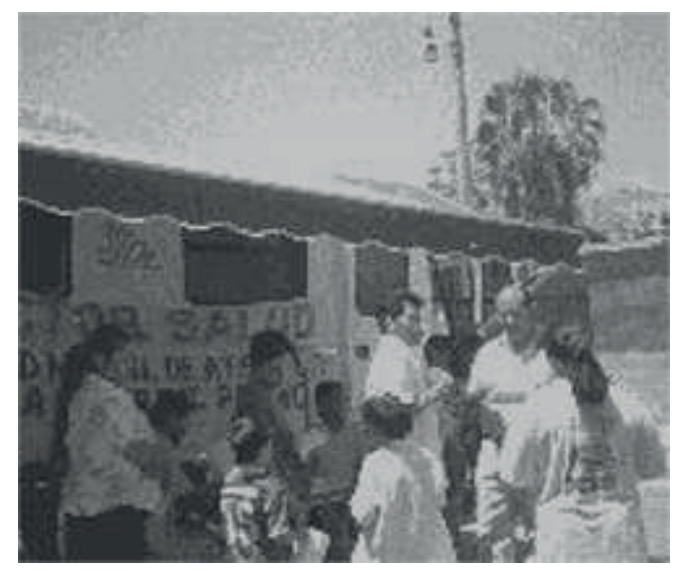

Personas afectadas por el plomo emitido por la empresa Met-Mex Peñoles en Torreón buscan atención médica en un módulo.

Foto archivo. Diario "La Crónica de Hoy", Saltillo, México. Imagen obtenida de www.webcom.com.mx/cronica/1999/jun/01/ med01.html

En 1993, Chile y Bolivia se comprometieron en la construcción de bodegas para el acopio de plomo en las afueras de Antofagasta, luego de descubrirse la existencia de niños de esa ciudad con altos niveles de plomo en la sangre. En esto tuvo gran participación la Comisión de Medio Ambiente del Colegio Médico de Bolivia, quienes, sin embargo, recibieron por respuestas argumentos como éste: "En Chile, la contaminación por plomo se produce esencialmente en los lugares de trabajo, y no existen estudios referidos a la evaluación del impacto de este mineral en la salud infantil". 
Estados Unidos, a pesar de sus estrictas leyes y normas en defensa de la ecología, la contaminación por plomo sigue siendo la amenaza número uno de la salud ambiental del país, pues uno de cada 11 niños de entre 1 y 5 años de edad tienen plomo sanguíneo, en especial los niños de las zonas más pobladas, como los estados de Nueva York y Nueva Jersey. La misma amenaza se aprecia en Colombia, país que, como el Perú, no ha desterrado la contaminación que invade sus ciudades procedente del plomo de las gasolinas y las emanaciones tóxicas y relaves en zonas industriales y mineras.

Mientras tanto, en Venezuela las cosas no están mejor: las áreas económicas con la mayor incidencia de contaminantes son la industria metálica básica (33,5\%), la construcción $(18,6 \%)$ y la manufacturera con $17 \%$. Caracas y Valencia son las ciudades más contaminadas del país. Aquí, las enfermedades ocupacionales más extendidas son la hipoacusia o sordera $(37,50 \%)$, la dermatosis, producida por cementos, detergentes y solventes $(32,34 \%)$ y saturnismo $(16,13 \%)$.

En Francia, el saturnismo infantil sigue siendo un grave problema sanitario. En 1992 se realizó un estudio en 20 departamentos, donde se detectó que de los 14.216 niños examinados, 13.400 presentaban una plumbosis inicial, de ellos 4000 (el 32\%) tenía un índice de plomo en la sangre superior a $100 \mathrm{ug} / 1$ (umbral a partir del cual es necesaria una intervención médica y sanitaria) y 700 niños (5\%) presentaban 250 $\mathrm{ug} / \mathrm{l}$.

Japón es tal vez uno de los países más contaminados del mundo, pero también es uno de los precursores en la aplicación de programas medioambientales de gran magnitud. En 1973, el Gobierno Metropolitano de la ciudad de Tokio diseñó un plan de protección a la ciudadanía contra los riesgos ambientales, con el objetivo de lograr y mantener las condiciones idóneas en la calidad del medioambiente. 
Por increíble que parezca, en algunos países europeos (España, Francia, Italia, Reino Unido, etc), pese a que existen rigurosas leyes contra la contaminación por plomo, muchas veces ocurre que éstas son sistemáticamente violadas por numerosas industrias (es lo mismo que decir: "hecha la ley, hecha la trampa"), mientras la población se queja de diversas enfermedades provocadas por las emanaciones de industrias que utilizan el plomo como materia prima.

\section{2 ...y el de más acá}

En nuestro país, la historia de la contaminación plúmbica, plumbosis o saturnismo siempre ha estado vinculada a la minería y la industria, convirtiendo a esta enfermedad en algo exclusivamente ocupacional, es decir, que sólo afecta a quienes laboran en actividades relacionadas con minerales como el plomo.

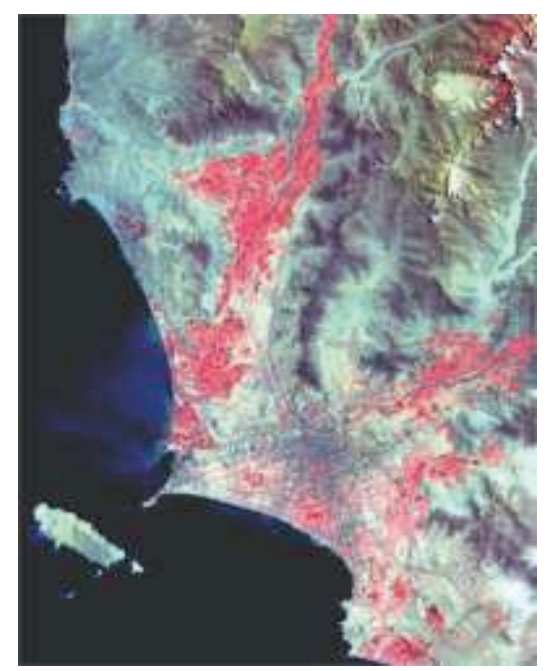

Foto por satélite del Área Metropolitana de Lima y Callao. Obsérvense las islas de San Lorenzo (grande) y El Frontón (pequeña), la península de La Punta (frente a San Lorenzo), el Terminal Marítimo (arriba de La Punta), el aeropuerto internacional Jorge Chávez (al norte, pegado al mar) y la Bahía de Chorrillos (al sur). En rojo las cuencas de los ríos Rímac (arriba) y Surco (abajo). Imagen obtenida de www.callao.org 


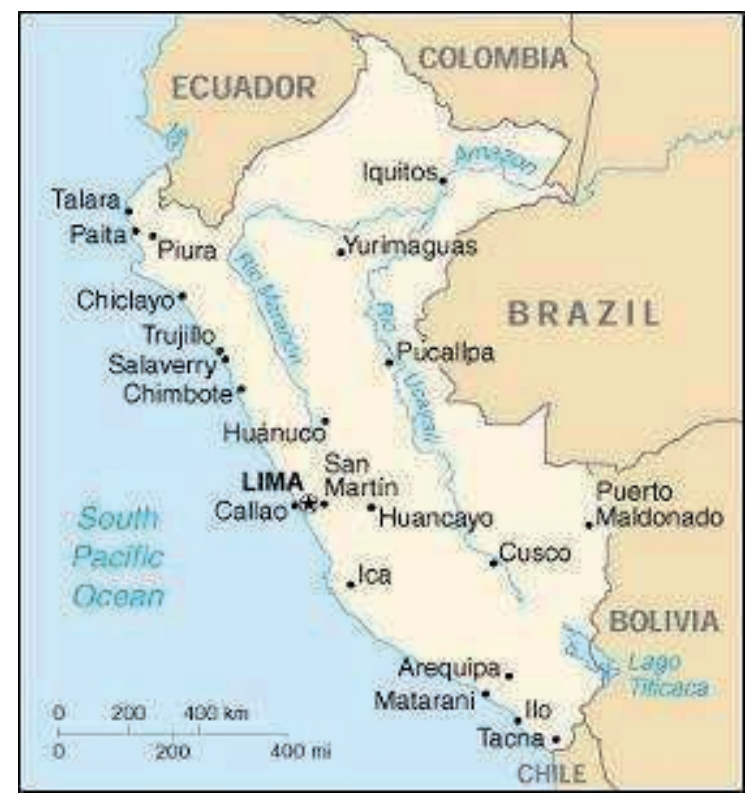

Mapa del Perú con la ubicación de Lima y Callao.

Imagen obtenida de www.pathfind.org/html/Worldwide/images/Peru.GIF

Sin embargo, es indudable que esta problemática sanitaria también está afectando a la población, que no necesariamente vive de la actividad minera o industrial, pero que la sufre a causa de la contaminación provocada por minas, refinerías, fundiciones, recicladoras, depósitos de minerales, etc. A pesar de las evidencias, los estudios realizados y la cada vez mayor cantidad de casos clínicos, sobre todo en la población infantil, esta situación todavía no ha sido encarada correctamente tanto por el sector público como por el sector privado.

Aunque en materia sanitaria ocupacional se ha avanzado algo en el Perú (en 1947 se dio la ley de prevención de enfermedades ocupacionales, creándose el Departamento de Higiene Industrial, el ahora Instituto de Salud Ocupacional del Ministerio de Salud) y se han creado organismos como DIGESA, la situación se ha visto agravada por la falta de planificación urbana y las migraciones provenientes de las provincias, fenómeno socioeconómico que data de la década de los '60 -llámese pobreza, hambre, miseria, desempleo, falta de oportunidades- y que llevó a miles de peruanos a emigrar a la capital en busca de mejores condiciones de vida. La ciudad entonces 
comenzó a crecer horizontalmente, de forma desordenada -originándose las llamadas "barriadas", nada que envidiar a las favelas de Río de Janeiro o los "ranchos" caraqueños- haciendo que las zonas industriales, ubicadas en las periferias, quedaran de pronto rodeadas de zonas urbanas o asentamientos humanos. Se podría decir que las zonas urbanas invadieron las zonas industriales.

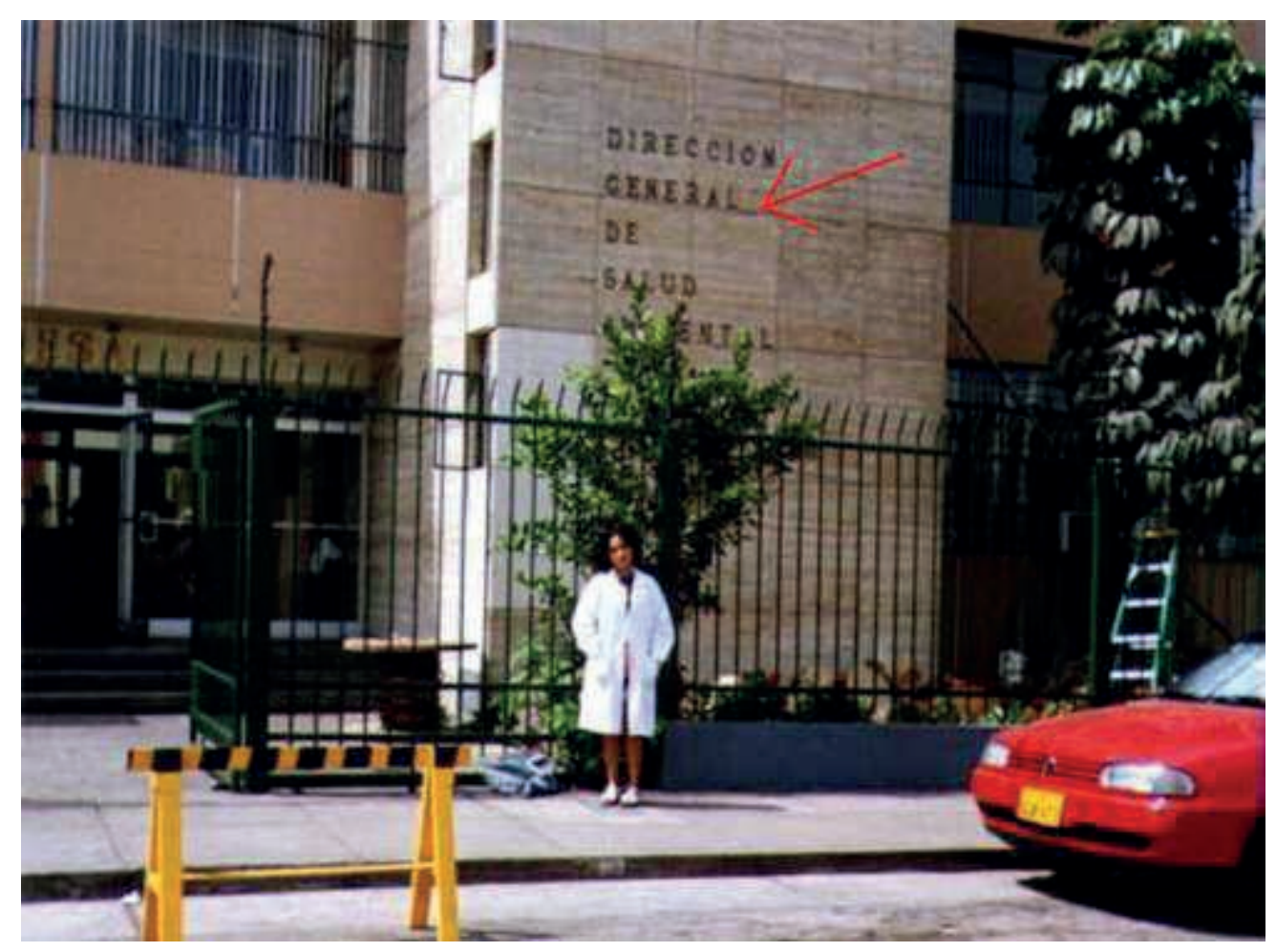

Carolina Isabel Guerra posa frente a la fachada del edificio de DIGESA, en Lima.

(Foto de Carolina Isabel Guerra)

Asimismo, la recesión de la década de los '90 provocó el colapso de muchas empresas en todo el país, y especialmente en Lima, una ciudad que engloba al 60\% de la actividad económica nacional. El desempleo y subempleo se ha traducido en la informalidad y el descontrol en las empresas, pues la crisis ha hecho que miles de trabajadores implementen talleres en sus propios hogares, es decir, en este caso, las industrias invaden las zonas urbanas. 
"El desconocimiento de la población peruana sobre la gravedad del tema -escribe Carolina Isabel Guerra-, y la situación de extrema pobreza (característica de los lugares más afectados), así como la inercia de las entidades del gobierno central y local, para enfrentar el problema con la urgencia que lo requiere, potencia los efectos de esta enfermedad pues por un lado no existe la sensibilización adecuada que haga que la población se proteja y exija el cumplimiento de las normas ambientales y por otro, existiendo legislación de protección ambiental, ésta no se hace cumplir con la severidad necesaria para proteger a la población vulnerable."

\section{Una historia larga como su tragedia}

Cuenta Carolina Isabel Guerra que en el Antiguo Testamento ya se habla de los efectos del plomo, y que la denominación del saturnismo proviene de la época en que el plomo era uno de los siete metales conocidos por los alquimistas, a los que ellos relacionaban con los siete planetas entonces conocidos (Mercurio, Venus, Tierra, Marte, Júpiter, Saturno y Neptuno) e identificaban el plomo con Saturno. Según las creencias medievales, que los europeos heredaron de la más rancia antigüedad, había una relación entre los hombres, su signo planetario y los metales. Los egipcios, por su parte, conocieron el plomo y lo utilizaron en el esmaltado de cerámicas. Precisamente ellos denominaron "cerusa" al material que utilizaban como cosmético para dar a la piel una tonalidad metálica.

En el Museo Antropológico de la Ciudad de Cagliari, en Italia, se conservan los restos óseos de unos individuos de origen púnico que muestran claras evidencias de haber sufrido una enfermedad muy común en quienes ingieren o inhalan plomo. Los huesos, datados entre el año 1300 y el 900 antes de Cristo, presentan anormalidades y fragilidad, típicos síntomas del saturnismo, como que los personajes vivieron y crecieron en ambientes saturados por este metal. 


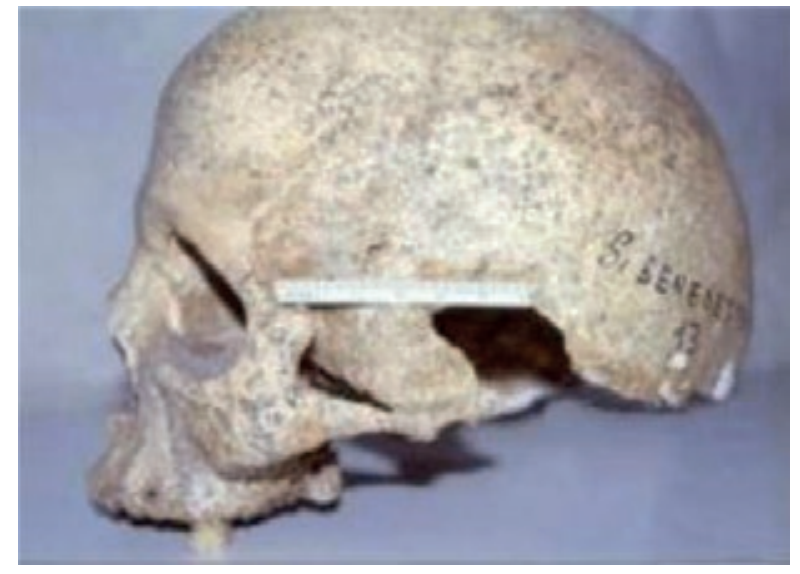

Este cráneo del periodo Nurágico que se conserva en el Museo Sardo de Antropología y Etnografía de Cagliari, Cerdeña, Italia, muestra evidencias de que su dueño padeció saturnismo, enfermedad que al parecer acabó con su vida.

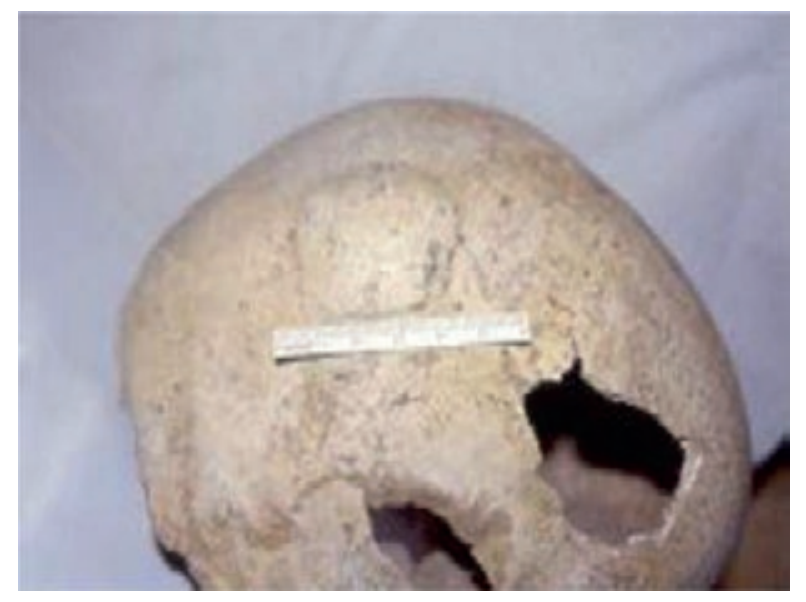

Otro cráneo del mismo periodo que nos enseña una terrible lección: esta gente convivió con la contaminación a flor de piel. Que duda cabe, el plomo llenó la vida cotidiana del pueblo sardo de aquellos tiempos, tal vez porque comerciaban o trabajaban con este metal, abundante en Cerdeña.

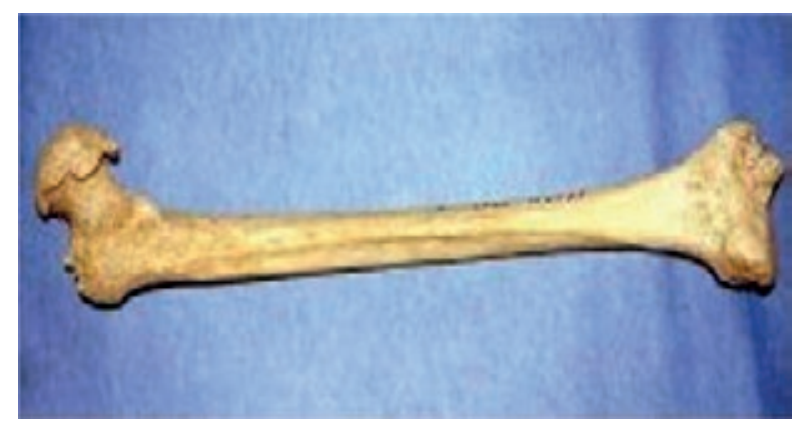

$\mathrm{El}$ individuo al que perteneció este hueso parece que también padeció la enfermedad del plomo, que lo acompañó toda su vida; las huellas del mal quedaron indeleblemente marcadas. Periodo Nurágico (1300-900 A. de C.)

Imágenes obtenidas de www.unica.it/ museoae/proto3.html

El médico griego Hipócrates de Cos (300 a. de C) fue uno de los primeros en mencionar la plumbosis como una enfermedad cuando describió algunos síntomas como cólicos, palidez, parálisis y disturbios oculares; por su parte, Pedacio 
Dioscórides Anazarbeo (año 100 de nuestra Era) descubrió que la ingesta de compuestos de plomo originaba cólicos, parálisis y delirio. A su vez, también se dice que las tuberías de plomo contribuyeron a la decadencia del imperio romano, pues eran muy utilizadas por sus clases privilegiadas.

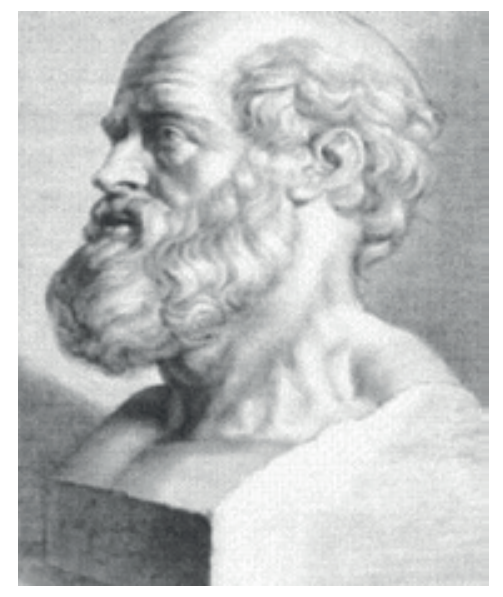

Hipócrates de Cos fue uno de los primeros en describir la plumbosis. Busto del siglo II A. de C.

Imagen obtenida de www.zuhaizpe.com/articulos /hipocrates.htm

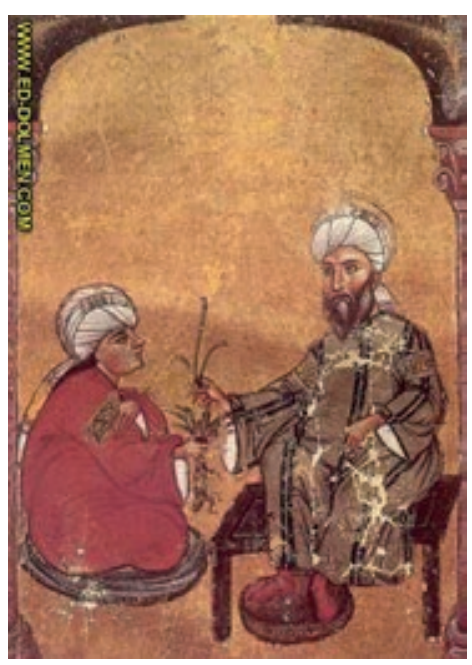

El médico griego Pedacio Dioscórides explicando a un alumno las propiedades de una planta en esta miniatura del siglo XIII. Imagen obtenida de www.artehistoria.com 


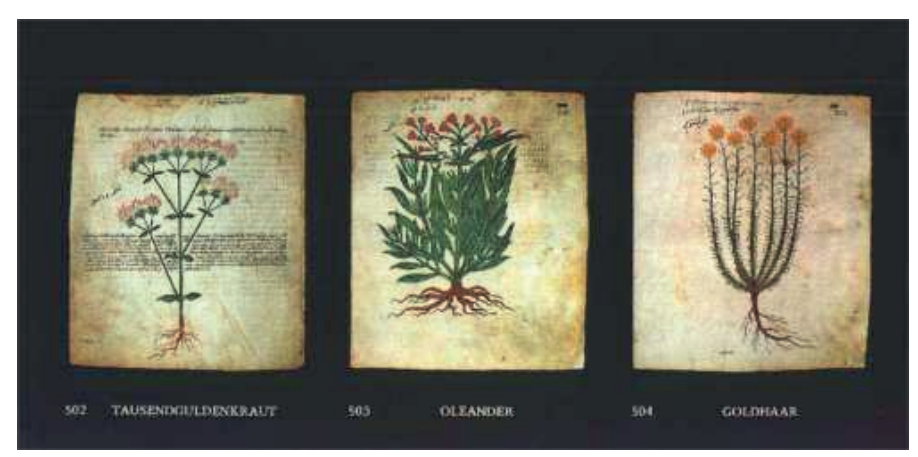

las propiedades de las plantas.

A Pedacio Dioscórides se le reconoce por sus aportes a la moderna homeopatía. Sus obras se convirtieron en la biblia de la nueva medicina, cuyas páginas revelan su gran conocimiento de http://www.balogh.com/austria/adeva2.html

En los siglos XVIII y XIX, el saturnismo fue conocido como la enfermedad de los artistas e inventores, pues al parecer un gran número de ellos la sufrieron. Así, el genial compositor Ludwig van Beethoven la contrajo por su desmedida pasión por el pescado contaminado del Danubio. También se sospecha que los pintores Vicent van Gogh y Francisco de Goya la sufrieron igualmente debido al albayalde de las pinturas que utilizaban para crear sus obras maestras. Algunos biógrafos cuentan que el inventor Benjamin Franklin, que solía utilizar este elemento en sus trabajos con la electricidad, también padecía síntomas sospechosamente parecidos a los del saturnismo.

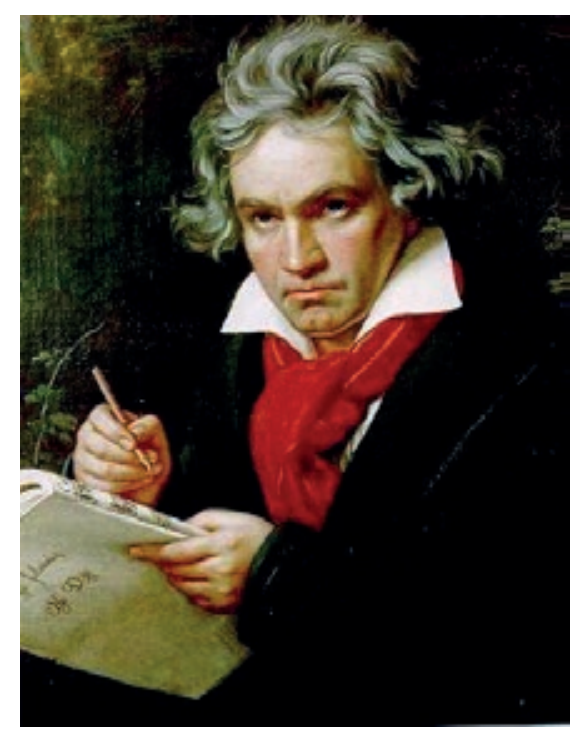

Un retrato clásico del genial compositor Ludwig van Beethoven. Se dice que su sordera fue consecuencia del saturnismo que finalmente lo llevó a la tumba. Imagen obtenida de $\underline{\text { www.gmd.de }}$ 


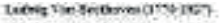

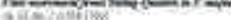

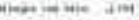

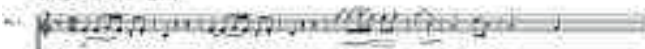

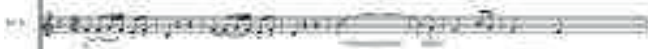

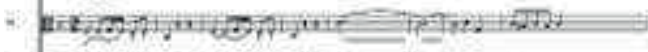

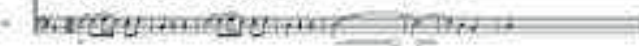

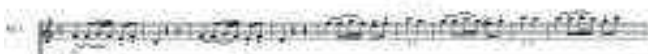

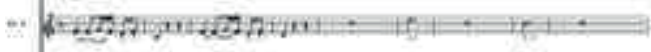

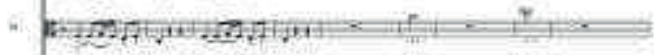

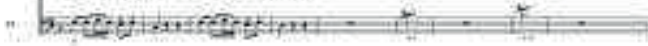
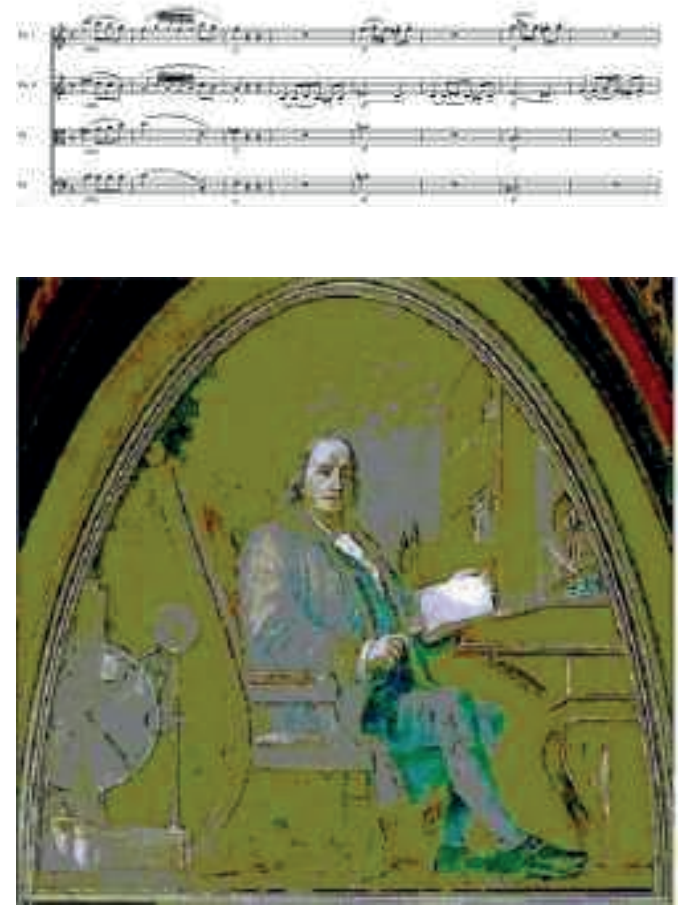

Nadie entiende cómo Beethoven pudo componer tanta belleza en medio del silencio. Aquí la letra musical original de su hermosa obra "Quartet en F Major, OP 18, No. 1", que el autor compuso entre 1798 y 1799.

Imagen obtenida de www.musedit.com/med/InstrFeatures/String /Beethoven-FmajQuartet-bb.htm

Fresco del artista Constantino Brumida. Imagen obtenida de www.aoc.gov/cc/art /brumidi_corr/franklin.htm 


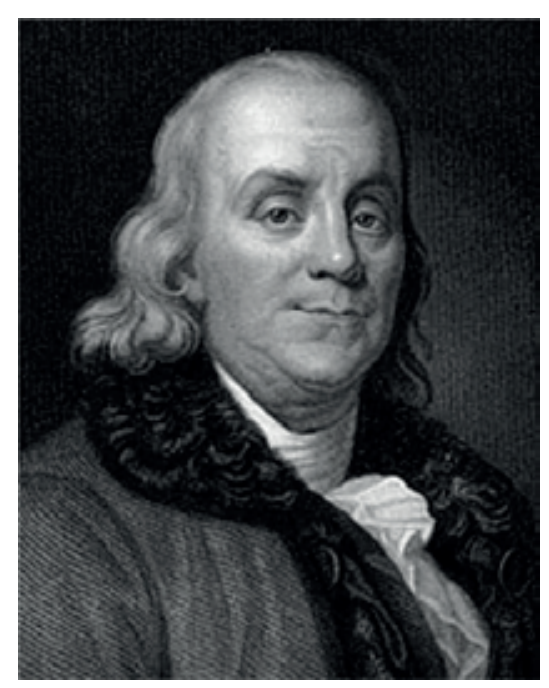

Retrato de Benjamin Franklin. Imagen obtenida de www.early.america.com/lives/franklin/portrait.html

Benjamin Franklin, "el cazador del rayo". Algunos biógrafos atribuyeron sus achaques al plomo que utilizaba en sus investigaciones

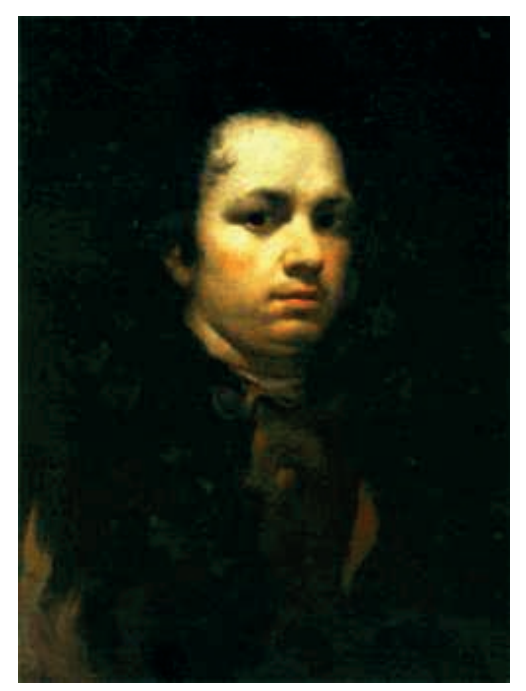

Autorretrato pintado por Francisco de Goya entre 177374. Hay biógrafos que atribuyen sus arrebatos de locura $\mathrm{y}$ alucinaciones al plomo que utilizaba en sus pinturas. Colección privada, Madrid. Imagen obtenida de www.imageone.com/goya/index1.html 


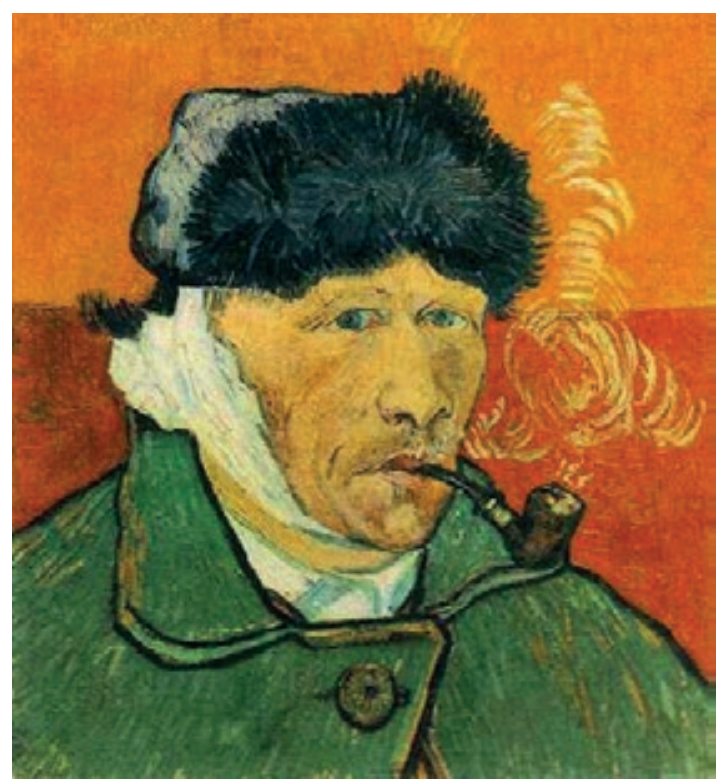

Así se pinto un demacrado y pálido Vicent Van Gogh, en enero de 1889, casi un año y medio antes de pegarse un tiro. Las diferencias con el otro autorretrato saltan a la vista.

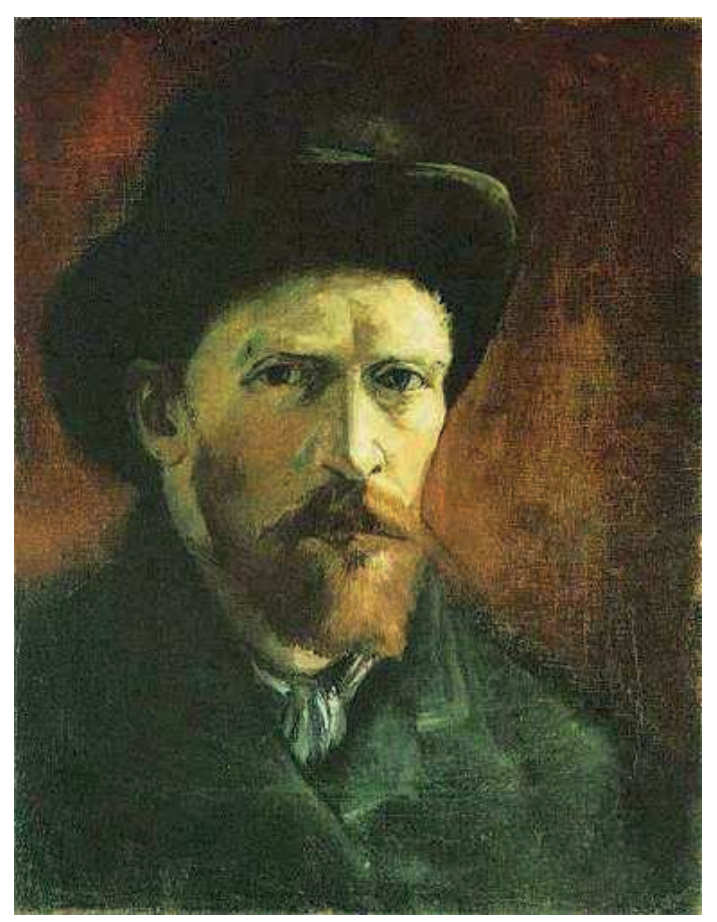

Autorretrato de Vicent van Gogh (1886), que se exhibe en el Amsterdam Art Museum, pintado cuatro años antes de su muerte.

Imágenes obtenidas de www.vangoghgallery.com 
En 1839, el clínico francés L’Tanquel des Planches publicó su obra en dos tomos, titulada "Traite des maladies de plomb ou saturniniens". Ochenta y seis años después, la Doctora Alice Hamilton (1869-1970), se convirtió en la pionera y fundadora de la salud ocupacional e higiene industrial modernas y una de las primeras mujeres que formaron parte del profesorado de la Escuela de Medicina de la Universidad de Harvard, a pesar del recelo de sus colegas varones, que la discriminaban por ser mujer. En mayo de 1925, comenzó a promover la salud de los trabajadores y la población en general. Publicó, como una contribución científica, en el Journal of the American Medical Association, un artículo en el que se discuten los daños en la salud asociados con el uso del plomo como detonante en las gasolinas. La Doctora Hamilton fue una crítica importante a los estudios realizados por el Departamento de Minas de los Estados Unidos y un estudio muy sólido sobre el riesgo del uso del tetraetilo de plomo. Tuvieron que pasar 60 años antes de que las autoridades reconocieran el valor de este trabajo... y decidieran retirar el plomo de las gasolinas en los Estados Unidos.

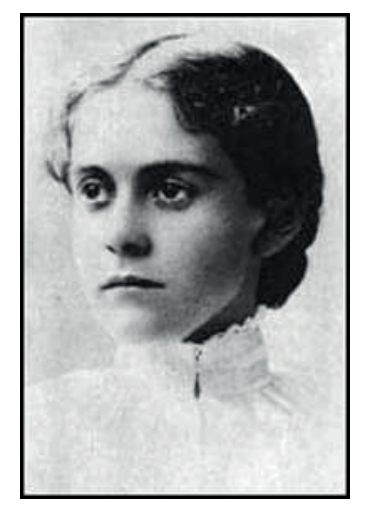

Hizo historia. La doctora Alice Hamilton luchó por la salud de los trabajadores y la población. Imagen obtenida de www.spartacus.schoolnet.co.uk

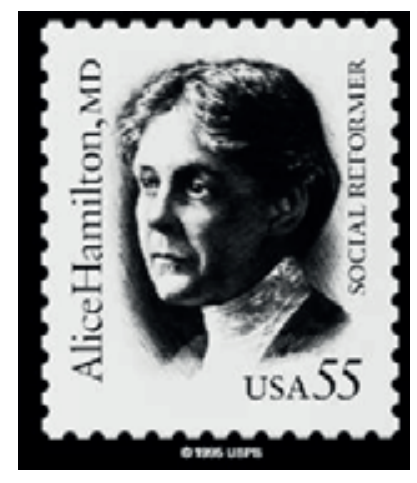

La doctora Alice Hamilton inmortalizada en este sello de correos. Su país le rindió un tributo tardío. Imagen obtenida de www.cdc.gov 


\section{9. ¿Sabía usted que...?}

-Las gasolineras (grifos) frente a hospitales y colegios -aunque tengan las "debidas medidas de seguridad"-, vehículos viejos que echan más humo que tren de la sierra y un aire irrespirable, son el corolario de una de las capitales más contaminadas de Latinoamérica.

-En el año 2001 había un promedio de 1.820 gasolineras sólo en la ciudad de Lima.

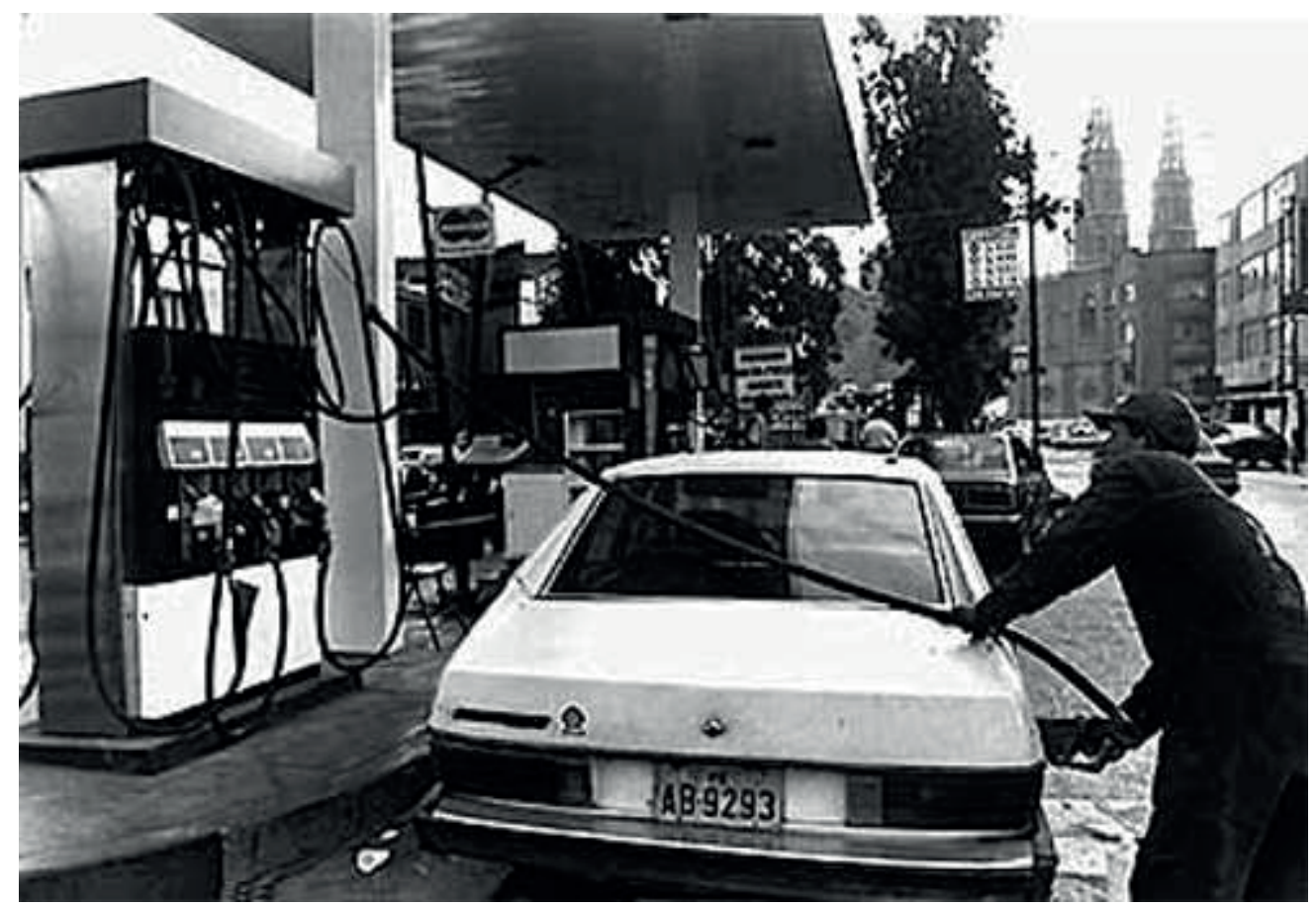

En plena acera (berma) de una avenida limeña, y en zona residencial, a esta gasolinera (grifo) no la mueve nadie. Imagen obtenida de www.caretas.com.pe

-Sólo en la céntrica avenida Abancay hay a ciertas horas más partículas de plomo por metro cúbico de aire que en toda la ciudad de Santiago de Chile.

-En 1998 se detectó plomo en la sangre de varios niños en el colegio Jesús Obrero de Comas, al norte de Lima. "El registro más alto que hallamos en este plantel fue de $27,9 \mathrm{mg} / \mathrm{dl}$ y le siguen alumnos con plomo sérico con niveles entre los 10,0 y 15,7 
mg/dl, es decir, todos presentan niveles tóxicos", advirtió en aquella ocasión la Dra. Resalía Anaya, directora del CICOTOX (UNMSA).

-El Perú ocupa el sexto lugar en la producción mundial de Plomo. Según cifras del Instituto de Ingenieros de Minas del Perú, la producción de plomo en nuestro país se elevó de 229.722 toneladas métricas en 1990 a 271.782 TM en 1999 (270.576 en 2000).

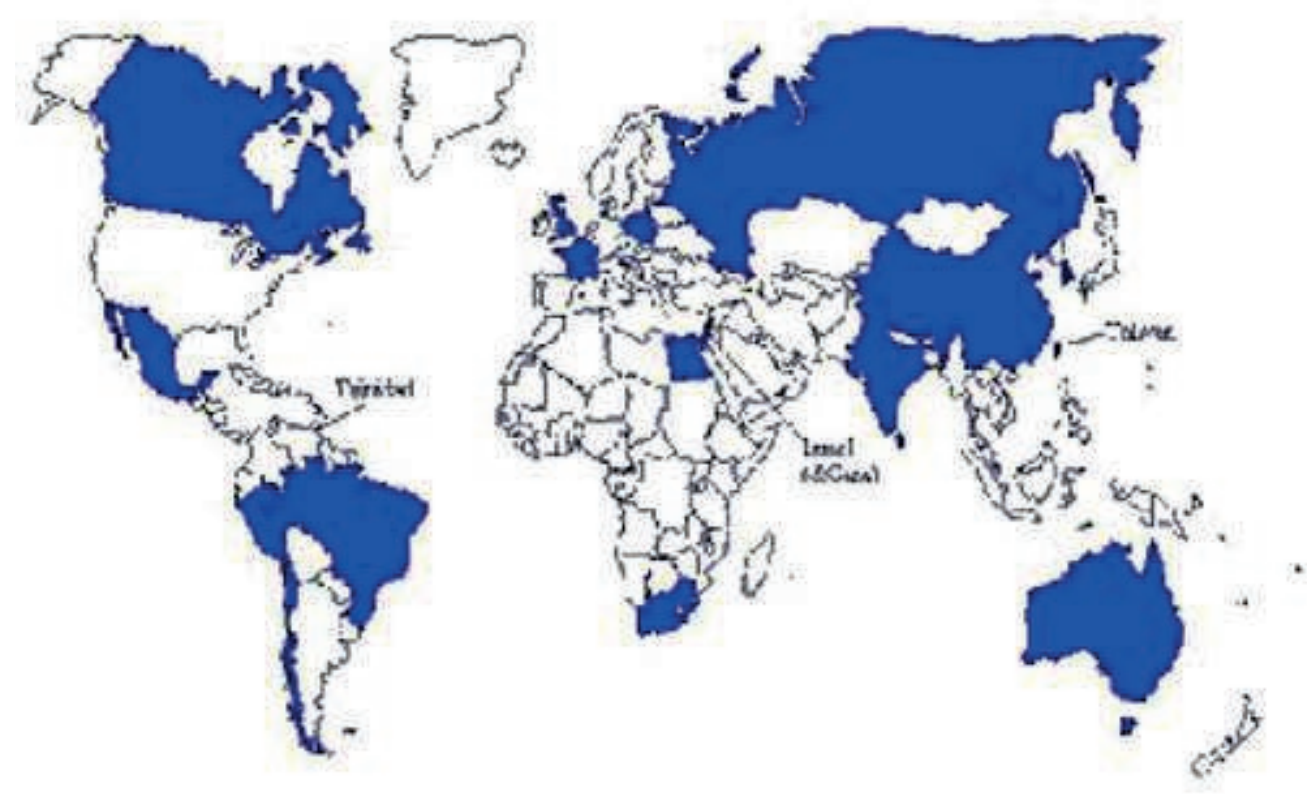

Mapamundi de los principales países productores de plomo. Imagen obtenida de www.cdc.gov/nceh/globalhealth/spanish/priorities/lead.htm

-En Pisco, puerto al sur de Lima, se dio el caso de una niñita de cinco años cuyo análisis de cabello arrojó $110 \mathrm{mg} /$ dl. de plomo. Curiosamente, su padre, trabajador en una fábrica productora de óxido de plomo y oxicloruro de cobre, arrojó en los análisis de cabello $140 \mathrm{mg} / \mathrm{dl}$. En la Oroya, se ha detectado plomo en la sangre de madres gestantes en un promedio de $39,49 \mathrm{mg} / \mathrm{dl}$.

-A comienzos del año 2004 se erradicará el plomo de las gasolinas de 84 y 95 octanos en el Perú. Todos los países latinoamericanos ya lo hicieron, salvo Panamá y Venezuela, que lo harán recién en el 2002 y 2007, respectivamente. 


\begin{tabular}{|c|c|c|c|c|}
\hline DISTRITO & $\begin{array}{c}\mathrm{N}^{0} \text { NIÑOS } \\
\text { CONTAMINADOS }\end{array}$ & $\begin{array}{l}\text { PROMEDIO } \\
\text { (mcg/dl) }\end{array}$ & $\begin{array}{l}\text { NIÑOS CON } \\
\text { MÁS DE } 10 \\
(\mathrm{mcg} / \mathrm{dl})\end{array}$ & $\begin{array}{c}\text { NIÑOS CON } \\
\text { MÁS DE } 20 \\
(\mathrm{mcg} / \mathrm{dl})\end{array}$ \\
\hline CALLAO & 581 & 9.5 & $33.40 \%$ & $6.20 \%$ \\
\hline $\begin{array}{l}\text { CALLAO } \\
\text { (dep. min) }\end{array}$ & 354 & 23.3 & $76.80 \%$ & $50.80 \%$ \\
\hline $\begin{array}{c}\text { CERCADO } \\
\text { LIMA }\end{array}$ & 523 & 7.3 & $21.00 \%$ & $1.10 \%$ \\
\hline COMAS & 341 & 7.7 & $17.00 \%$ & $1.40 \%$ \\
\hline LA MOLINA & 219 & 6.0 & $7.00 \%$ & ---- \\
\hline LINCE & 282 & 7.6 & $17.00 \%$ & $1.00 \%$ \\
\hline $\begin{array}{c}\text { PUEBLO } \\
\text { LIBRE }\end{array}$ & 206 & 6.6 & $14.00 \%$ & $3.90 \%$ \\
\hline
\end{tabular}

Fuente: Dirección General de Salud DIGESA

(El Comercio 07-10-99)

\section{1 ...el plomo está en}

...las gasolinas de 84 y 95 octanos, que utilizan plomo como detonante.

...las bencinas de automóviles.

...ciertas pinturas para el hogar

...los juguetes infantiles -como algunas muñecas-.

...plastilinas, mayólicas y yesos.

...las baterías y pilas.

...las pesas de los aparejos de pesca.

...en ciertas vajillas y cerámicas.

...los utensilios de barro.

...en el cemento y el hormigón.

...en algunos artículos de plástico industrial. 
...las persianas elaboradas con este metal -que desprenden partículas de plomo.

...el agua almacenada en pipas o tinajas de metal que tienen soldaduras de plomo.

...los alimentos enlatados o preparados en recipientes con soldadura de plomo.

...las sales de plomo que contienen algunos remedios populares como el azarcón -un polvo de color anaranjado que contiene entre 86 y 95 por ciento de tetróxido de plomo-, la greta y el albayalde, utilizados para tratar los "empachos" o molestias intestinales -frecuentemente atribuidas al exceso de comida.

...en los hospitales -donde abunda, especialmente en las áreas de rayos "X".

...en el aire que respiramos -si vivimos cerca de contaminates sólidos.

...etc.

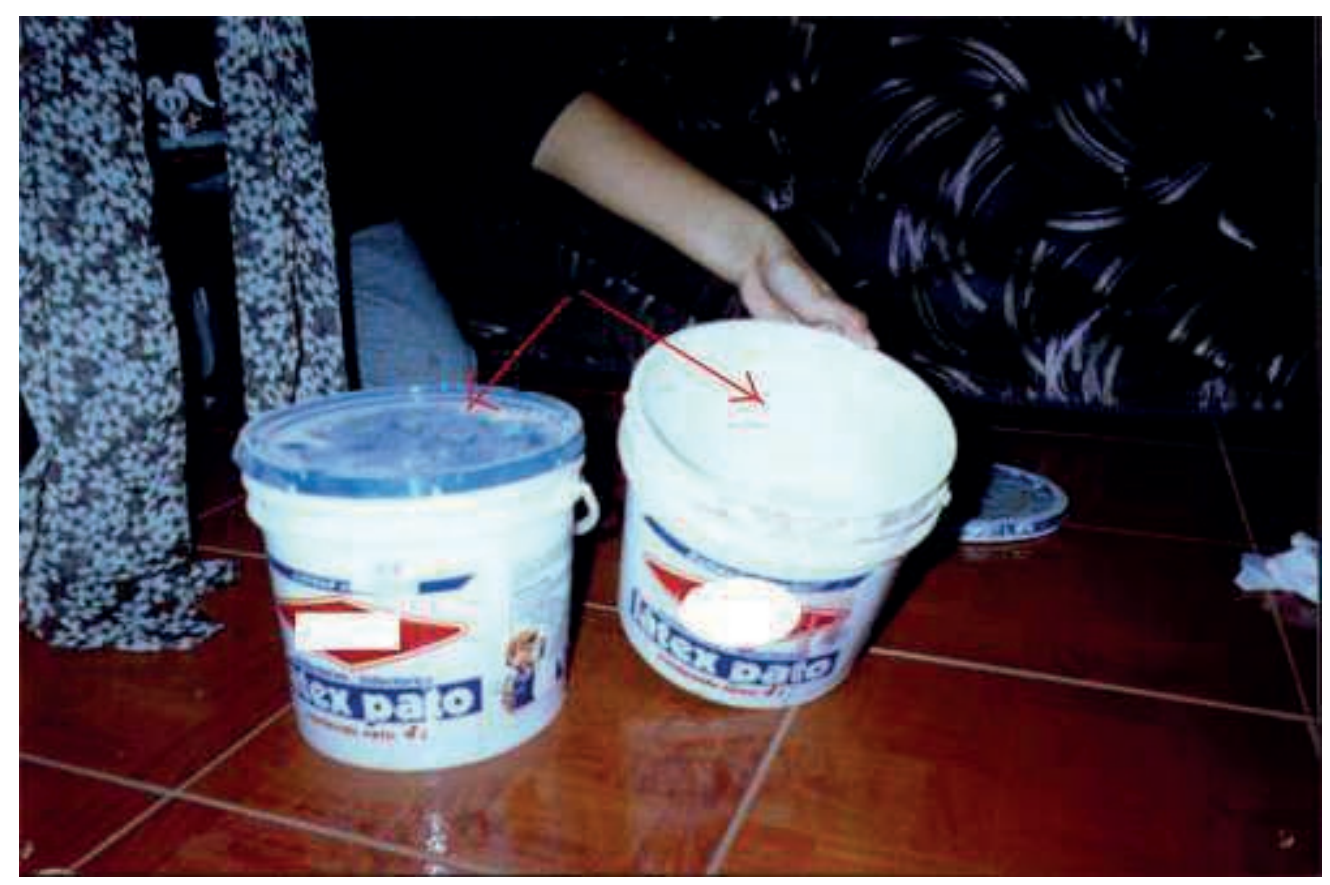

Mientras en otros países ya se ha prohibido el uso de pintura de paredes que contengan plomo, en el Perú todavía no se habla de una campaña gubernamental para erradicar las fuentes de contaminación y proteger a la población. La desidia e indiferencia son tales, que los estudios realizados por diferentes instituciones sobre los efectos nocivos del plomo, no han merecido la atención de las autoridades.

(Foto de Carolina Isabel Guerra) 


\subsection{Ficha técnica del plomo como contaminante}

Nombre: Plomo (de gris)

Símbolo: $\mathrm{Pb}$

Características del contaminante: Metal pesado, no ferroso, que se presenta en forma de vapor, aerosol o polvo.

Fuentes principales: Combustión de gasolina con plomo, minería, fundición y procesos industriales.

\section{Epílogo}

\subsection{Los niños del plomo}

El portal de Internet http://www.callao.org/plomo ha publicado un informe que conmueve pues sus protagonistas son niños, inocentes criaturitas que a su tierna edad sufren los efectos devastadores de la contaminación sin tener ellos culpa alguna. El contenido de dicho informe, preparado por el doctor Carlos Cousins, de la Dirección General de Saneamiento Ambiental (DIGESA) es tan revelador que hemos preferido transcribirlo textualmente, en la tabla siguiente:

\section{$\underline{\text { Síntomas de la intoxicación por plomo }}$}

En los niños los síntomas suelen aparecer a partir de los $30 \mathrm{ug} / \mathrm{dl}$. La persistencia de estos niveles suele provocar disminución de la agudeza visual y auditiva, retraso mental, déficit del lenguaje, problemas de aprendizaje, conducta y rendimiento escolar, además de alteraciones del equilibrio. Los efectos son mayores, cuanto más prolongada sea la exposición al plomo o si se produce en torno a los dos años de vida. 
En los huesos largos de los niños, cuando la exposición es prolongada, el plomo suele depositarse en las áreas de formación de hueso, lo que va dejando líneas transversales de plomo, que pueden ser visibles radiológicamente.

La intoxicación crónica es más frecuente e inespecífica. No es raro que los pacientes visiten variados médicos y se les diagnostiquen patologías psiquiátricas, psicosomáticas o fatiga crónica.

Patrick Mejía Cusiramos, 5 años, porta un cartel con sus datos generales, la única diferencia con un niño normal es que Patrick lleva plomo en su sangre y en su medula ósea, 37,14 ug/dl. Patrick es una buena muestra pues; el promedio de plomo en los niños de estos barrios es de 38,8 ug/dl (ver informe Digesa pdf). Ellos tienen un futuro marcado por el plomo, necesitan un sofisticado tratamiento de manera urgente, y obviamente una reparación al daño recibido. Según el último informe publicado por DIGESA, alrededor de 23.000 niños chalacos, que habitan en los barrios ubicados alrededor del Terminal Marítimo (Chacaritas, Puerto Nuevo, Frigorífico, Guardia Chalaca y Barrio Fiscal \# 3) sufren de intoxicación por plomo.

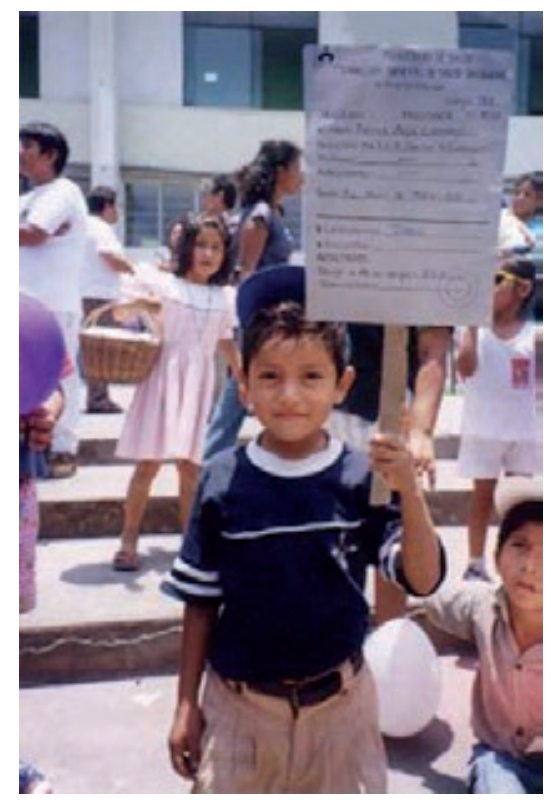

¿Alguien puede responder por qué el pequeño Patrick Mejía, a sus 5 años, sólo pesa 16 kilogramos, mide apenas 105 centímetros de estatura y tiene 37,14 de plomo? Foto obtenida de www.callao.org/plomo 


\begin{tabular}{|l|c|}
\hline \multicolumn{1}{|c|}{ Niños del Plomo } & ug Pb/dl \\
\hline Enzo Ochoa Colan & 40,00 \\
\hline Miguel Ángel Sánchez & 34,29 \\
\hline Karen Callan Ballasco & 30,00 \\
\hline Alex Atencio Limas & 60,00 \\
\hline Patrick Mejía Cujirramos & 37,14 \\
\hline José Pérez Buleje & 14,29 \\
\hline Cristian Callan Ballasco & 20,00 \\
\hline Yoharii Sánchez Suico & 28,57 \\
\hline Carolina Pérez Buleje & 25,71 \\
\hline Nicole Checa Cujirramos & 17,14 \\
\hline Franco Estrada Suico & 28,57 \\
\hline Rebeca Temoche López & 26,67 \\
\hline Juan Joaquín Yanqui & 23,33 \\
\hline Jorge Cortez Martínez & 22,36 \\
\hline Yeraldine Sánchez Suico & 28,57 \\
\hline Guillermo Callán Ramos & 40,00 \\
\hline Miguel Calderón Acosta & 20,00 \\
\hline Alejandro Paredes Acosta & 26,67 \\
\hline Joselín Paredes Acosta & 17,14 \\
\hline Jackeline Najarro Obregón & 34,29 \\
\hline Rect & \\
\hline
\end{tabular}

Relación incompleta de niños afectados por el plomo en el Callao. Informe de Ensayo N 13175 - 2001 del 28/11/2001 del Instituto de Salud Ocupacional del Ministerio de Salud del Perú. Se analiza plomo en sangre, método 8003 -ISSUE2-N1OS11, técnica Quelación - Extracción por Absorción Atómica. 


\subsection{Paren la contaminación por plomo}

Patrick, su mamá y muchas familias de los barrios de Ciudadela Chalaca, Puerto Nuevo, Chacaritas, Santa Marina, están pidiendo a las autoridades que pare la contaminación por plomo ahora. Ellos participaron de una marcha al Municipio del Callao para que el alcalde cumpla con cerrar los depósitos de concentrados de plomo mientras éstos continúen contaminando la ciudad. Con impactantes gritos de: ¡vida sí, muerte no!, y demandas contra el propio alcalde, los manifestantes estuvieron más de una hora soportando el asfixiante calor del verano chalaco.
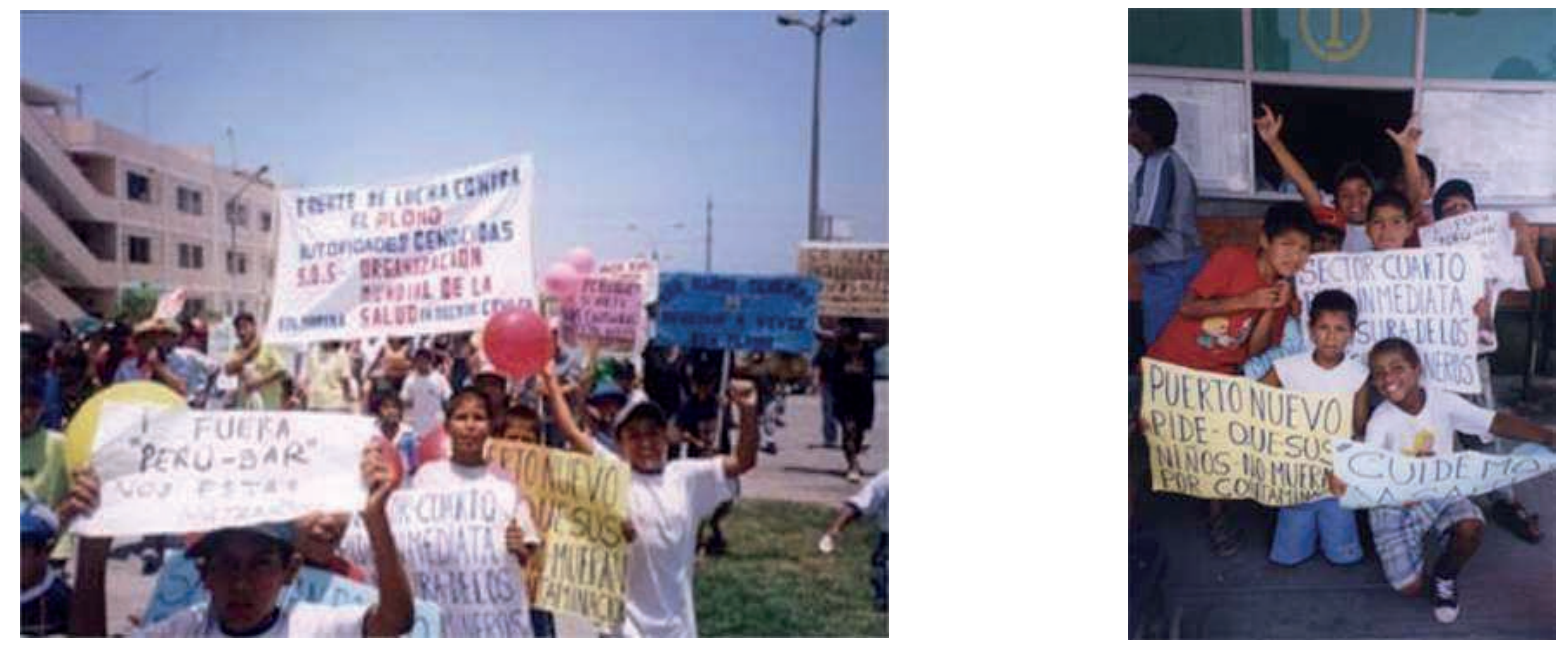

Marcha del plomo. Manifestación infantil contra el plomo en El Callao. No cabe duda que los niños del Callao, a su tierna edad, son conscientes del peligro que corren, no por culpa de ellos. ¿Respetarán sus derechos a vivir saludables? Imágenes obtenidas de www.callao.org/plomo 


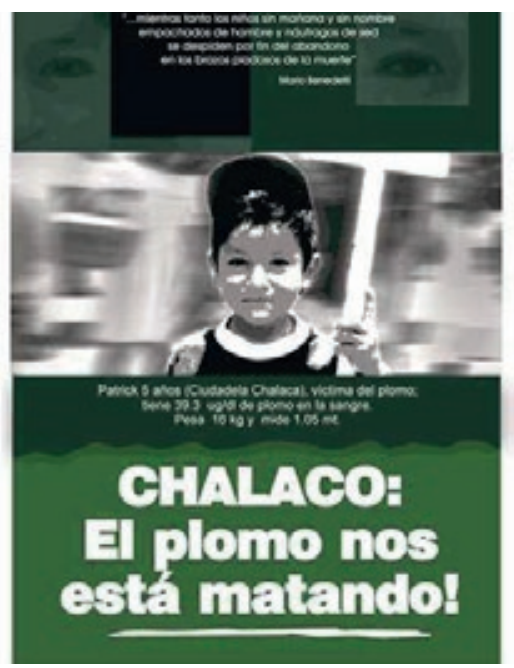

Cartel de la campaña contra la contaminación por plomo en el Callao, Perú. Diseño Elsa Herrera Quiñónez. Imagen obtenida de www.callao.org/plomo

\subsection{El Callao, sólo un botón de muestra...}

-Por el puerto del Callao, según las estadísticas de la Dirección General de Minería del MEM, se exportan 216.700 toneladas métricas /año, de plomo.

-El plomo que llega a nuestro Primer Puerto para ser almacenado en depósitos al aire libre, proviene de:

a) Del Sur: Caudalosa; San Valentín y Uyucassa 12.000 tm/año 5,5\%

b) Del Norte: Colquisiri, Magistral, Norperu, Pachapaqui, Toma La Mano, Vizcarra. $27.700 \mathrm{tm} /$ año $12,5 \%$

c) De la Sierra Central: 177.000 tm/año $82 \%$

-El plomo llega al Callao por ferrocarril: 55.500 tm/año 25,4\%, y en camión: 161.200 tm/año $74,6 \%$.

-Según las cifras, el problema no sólo está en los depósitos en tránsito a los barcos, sino en toda la ruta de transporte donde se va regando el mineral. 
-El 30 de noviembre del 2001 el Congreso aprobó una moción multipartidaria, pidiendo al ministro de Transportes, Luis Chang, que tome las acciones para que se haga realidad el Proyecto Eco Callao.

-El 18 de septiembre del 2001 una Resolución Directoral de la Dirección de Salud de El Callao, declara al Cercado de El Callao en emergencia sanitaria por la contaminación e intoxicación con plomo.

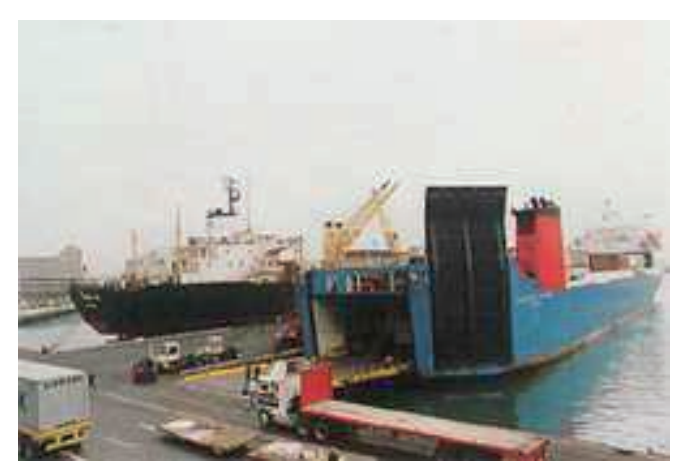

Del Callao sale la mayor parte del plomo peruano. Imagen obtenida de http://www.dicapi.mil.pe/capitanias.html

\section{Recortes}

\section{$\underline{\text { Las empresas más contaminantes del territorio español }}$}

Se hallan, según Greenpeace, en las siguientes zonas:

1.- Almadén (Ciudad Real), donde existe un autentico vertedero de doce mil toneladas de residuos extremadamente tóxicos.

2.- Flix, en Tarragona, es una zona que soporta quince puntos de vertido de sustancias tóxicas al río Ebro provenientes de una empresa de productos clorados. Sin ir más lejos, el 24 de enero de 1996, una fuga de 6 tm. de cloro causó la alarma en la población, fue el escape de este elemento más grave ocurrido en Europa. En aquel entonces, la fiscalía pidió 36 años de cárcel para sus directivos y 3.000 millones de 
pesetas de multa. No obstante, según la misma fuente, la empresa ha vertido durante años al Ebro productos tan tóxicos como el DDT o los PCBs, que se relacionaron con la mortandad masiva de delfines en el Mediterráneo.

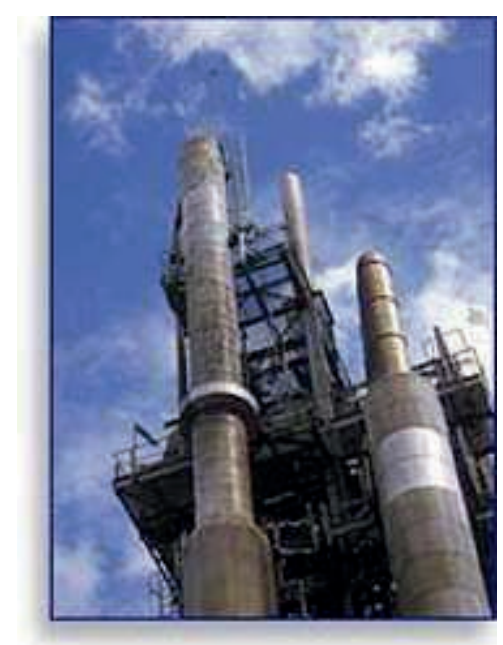

La factoría electroquímica de Flix, en Tarragona. Imagen obtenida de "Química Básica", cuyas emanaciones tóxicas no inmutan a las autoridades. Imagen obtenida de http://www.ercros.es/esp/dret/2activid/1negocio/qui mica.htm

3. Vilasec, también en Tarragona, recibe los vertidos al suelo de residuos tóxicos contaminados con disolventes, metales pesados y las temidas dioxinas procedentes de una fábrica que produce plástico clorado PVC. Las organizaciones ecologistas sostienen que esta empresa arrojó durante años toneladas de residuos en un descampado de la zona. Tras la denuncia de Greenpeace, los análisis de la Generalitat muestran niveles de contaminación tan espectacularmente altos que sólo se conocen dos casos más elevados en todo el planeta.

4.- Huelva, donde el conjunto del Polo Petroquímico resulta un auténtico museo de los horrores ecológicos. Los contenidos de cobre, plomo y zinc hallados en su estuario son los más altos del mundo. Aunque es difícil elegir entre los causantes de la catástrofe medioambiental, la papelera destaca por los niveles de contaminación y elementos que arroja a las aguas. En la ría se registran vertidos con organoclorados, empleados en el blanqueo de la pasta de papel 


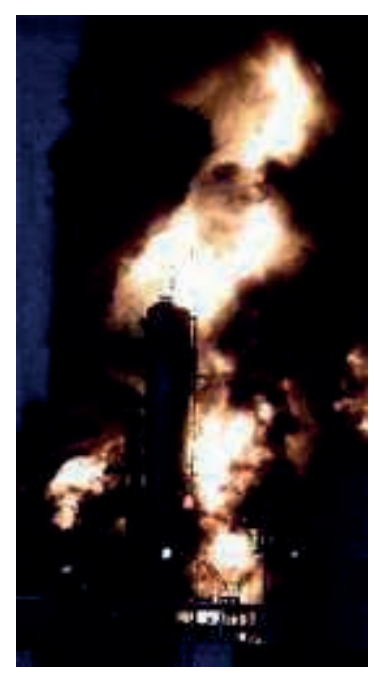

Este fuego se levantó recientemente en la refinería de Cepsa, en el Polo Petroquímico de Huelva. Si bien no se registraron heridos, el incendio desató las protestas de grupos ecologistas y la opinión pública por las constantes agresiones al medio ambiente de las industrias petroquímicas en esta región de España. Foto de EFE/Miguel Vázquez, publicada en El Periódico de Cataluña. Imagen obtenida de $\underline{\text { www.elperiodico.com/online/apuntador.asp?data }=\mathrm{ed} 011009 \& \mathrm{i}}$ dioma=CAS\&publicacion $=$ catalunya\&urlname=http: / $/$ www.el periodico.com/EDICION/ED011009/CAS/CARP01/tex049.asp

5.-Martorell, en Barcelona. Por una parte, cuenta con una fabrica de PVC que ha sido condenada por verter dioxinas y sustancias cloradas al río Llobregat. Por otra, tiene varias incineradoras en tan precario estado que, según Greenpeace, emiten sustancias tóxicas al medio ambiente.

6.- Portman, en Murcia, presenta toda la zona anegada por vertidos de residuos con alta concentración de metales pesados, supuestamente procedentes de una empresa minera.

7.- Euskadi. Además de los residuos depositados en las márgenes del Nervión, procedentes de las acerías, la contaminación por vertidos de lindane resulta alarmante en otros quince puntos, entre los que destacan Barakaldo y Erandio. La producción durante años de este peligroso elemento en la factoría de Bilbao Chemical -hoy cerrada- ha dejado una herencia de miles de toneladas de residuos altamente tóxicos. Desgraciadamente, el lindane se sigue utilizando en España, incluso por el Organismo de Parques Nacionales. Asimismo en Zaramillo (Vizcaya), una empresa continúa con la producción y comercialización de CFCs clorofluorocarbonos-, responsables de la destrucción de la capa de ozono, pese a tratarse de una actividad prohibida en Europa desde 1994. 
8.- Sabiñánigo (Huesca), donde la ahora cerrada empresa Inquinosa ha dejado como huella maldita vertidos de miles de toneladas de lindane.

9.-Pontevedra es otra zona que registra en su ría unos niveles elevadísimos de contaminación, debidos, entre otros elementos, al cloro que vierte la papelera.

10.- Zaragoza. Aparte de la fábrica de papel que vierte organoclorados al río Gallego, de hecho ya ha sido condenada por delito ecológico, se ha producido la primera incautación de CFCs ilegales en una empresa.

\section{$\underline{\text { Cormin modernizará depósito de imex Callao en seis meses }}$}

Cormin realizó una inversión inicial de US\$ 2,5 millones en la que se incluye el monto desembolsado por la adquisición de Imex Callao y lo destinado al mejoramiento de algunas zonas adyacentes al depósito. Asimismo inició la construcción de un depósito de 8.000 metros cuadrados para almacenaje y manipulación de concentrados de plomo. El año pasado facturó alrededor de US\$ 167 millones; la que descendería a US\$ 160 millones este año por la reducción de la cotización de los metales.

Tras señalar que Consorcio Minero (Cormin) inició la modernización de su recientemente adquirido depósito, que pertenecía a Imex Callao, Ricardo Trovarelli Vecchio, director gerente general de la empresa, informó que el plazo para la modernización del nuevo local sería de aproximadamente seis meses.

En ese sentido indicó que el plan de modernización implica un manejo completo del tema ambiental y del mejoramiento de la eficiencia del depósito.

Como se recuerda Cormin se adjudicó en agosto, en el marco de la privatización, la buena pro para adquirir el $100 \%$ de las acciones de Imex Callao (subsidiaria de Centromin Perú), tras ofertar por ella 77\% del precio base (US\$ 125 mil más IGV), aportando además US\$ 1 millón por el 100\% de las acciones de esta empresa estatal. 
Pese a no señalar la inversión total que se requeriría para la modernización del depósito, indicó que la inversión inicial contempla US\$ 2,5 millones (incluido lo pagado por la adquisición de la empresa estatal).

El ejecutivo señaló que Cormin se fusionará con Imex Callao el primero de noviembre bajo la modalidad de absorción por parte de Cormin.

Etapa inicial:

En ese sentido mencionó que la etapa inicial contempla la adecuación de toda la zona adyacente al yacimiento que conllevará a la plantación de árboles y de adecuación de jardines; además de la construcción de algunos muros.

Asimismo señaló que se ha iniciado la construcción de un depósito de 8.000 metros cuadrados herméticamente cerrados para almacenaje y manipulación de concentrados de plomo con ventilación invertida, lavado de camiones y vagones.

"Actualmente el plomo se almacena en una zona cerrada por mallas con estructuras metálicas y tela plástica, mientras que el depósito va a ser totalmente cerrado", sostuvo.

Trovarelli indicó que la intención de Cormin es convertir Imex Callao en un depósito con un excelente manejo del tema ambiental, como lo habrían hecho en su local de la avenida Gambetta de 33.500 metros cuadrados y que maneja alrededor de 400 mil toneladas de concentrados.

"Imex Callao es un depósito de 77 mil metros cuadrados y la ventaja es que está a 500 metros del puerto en acceso de ferrocarril y camiones. Es un depósito que necesita mucha inversión y en el que el lavado de los camiones es con manguera. Nuestra intención es poner tres balanzas con el sistema de lavado automático", señaló. 
Asimismo Cormin ha dispuesto la adquisición de dos barredoras-aspiradoras, las que unidas a la que tenía Imex y la que se encontraba en el local de Gambetta, sumarán cuatro barredoras-aspiradoras que mantendrán limpio el recientemente adquirido depósito.

Nuevas operaciones:

Ricardo Trovarelli informó que otras obras que se contemplan son la instalación de un muestreo para siete camiones, maquinaria para mezclar (que sería adquirida en Alemania a fin de mes) y la instalación de un laboratorio en el primer piso.

Cormin manejará 1,2 millones de toneladas en el depósito de Imex Callao. Aproximadamente $11 \%$ de los concentrados que se almacenan en el depósito son de plomo, por lo que indicó que se están tomando todas las medidas contra una posible contaminación.

\section{Exportaciones:}

Trovarelli indicó que el puerto del Callao exporta 1,6 millones de toneladas de concentrados de cobre, plomo y zinc. Además importa 100 mil toneladas de cobre así como 60 mil toneladas de carbón para la refinería de La Oroya. Las últimas dos operaciones las tiene en su totalidad Cormin (importación de cobre y carbón), las cuales destina a la Refinería de La Oroya perteneciente a Doe Run. Mientras tanto exporta alrededor de 940 mil toneladas de concentrados, por lo que tendría el $60 \%$ de las exportaciones de concentrados embarcados en el Callao, señaló.

Cormin maneja el negocio de embarque, desembarque y almacenamiento de concentrados, y también se dedica al trading de estos minerales. El año pasado facturó alrededor de US\$ 167 millones, teniendo utilidades que sobrepasaron el US\$ 1 millón. Pese a que este año la empresa incrementó en 10\% sus volúmenes en el manejo de concentrados, la facturación descendería a US\$ 160 millones debido a la reducción de los precios de los metales. 


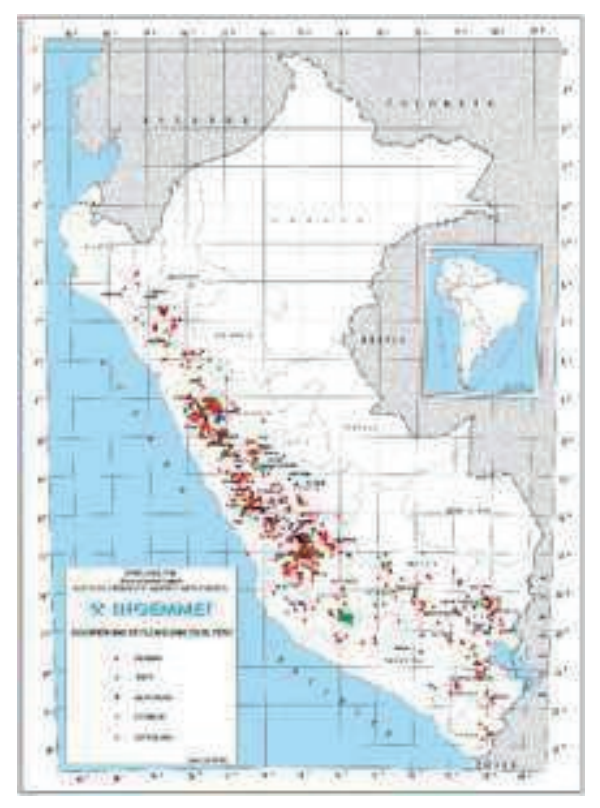

Mapa con las zonas productores de plomo y zinc en el Perú. Imagen obtenida del Instituto Geológico Minero Metalúrgico del Ministerio de Energía y Minas de Perú. www.ingemmet.gob.pe

Es necesario indicar que Cormin -subsidiaria de la holandesa Trafigura- maneja desde el Perú operaciones similares en Chile, Bolivia y México, con las cuales maneja alrededor de 500 mil toneladas.

\section{Anexo: Proyecto Eco Callao}

(Artículo publicado en www.callao.org como parte de su campaña contra la contaminación por plomo en esta jurisdicción)

Eco Callao es un proyecto que tiene por objeto solucionar técnicamente el problema de contaminación generado por el transporte de los minerales al puerto del Callao. Actualmente se transportan por ferrocarril hasta los depósitos ubicados en las cercanías del Terminal Marítimo, y luego con camiones de tolva hasta el propio terminal.

Eco Callao propone construir un almacén totalmente cerrado, incluso con presión negativa, para evitar la volatilización del polvo fino y desde este depósito llevarlo por una faja transportadora subterránea hasta la bodega de las embarcaciones. 


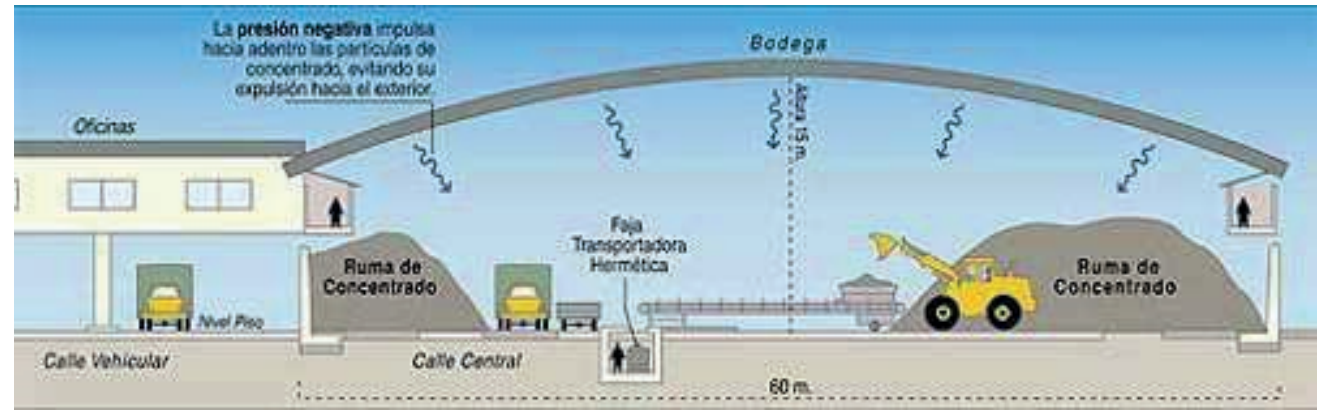

Así serían los depósitos cubiertos de mineral, que reemplazarían a los actuales, según el proyecto Eco Callao. Ilustración obtenida de www.caretas.com.pe

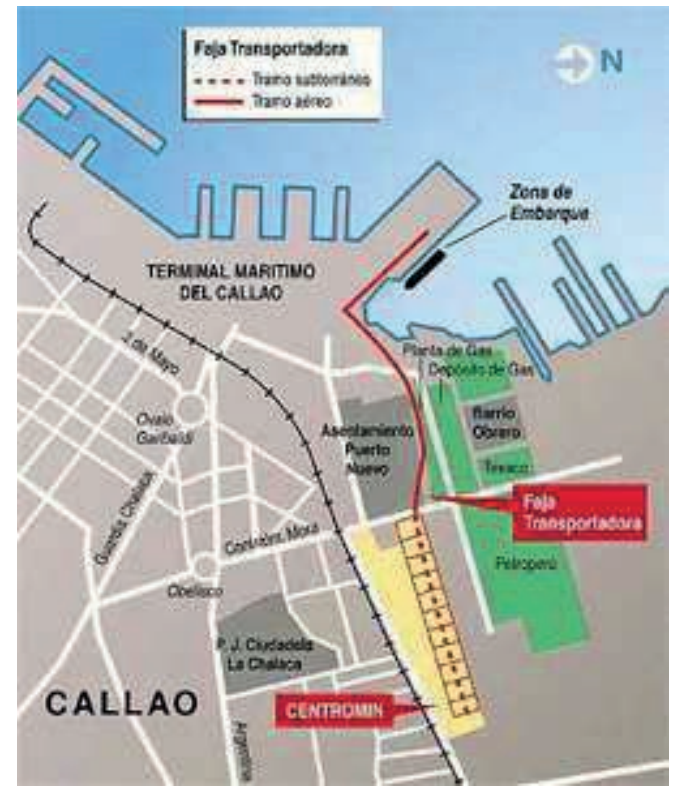

Según el Proyecto Eco Callao, así sería el futuro trazado de la cinta transportadora que llevaría el mineral al terminal marítimo, para solucionar el grave problema de contaminación que aqueja a la población chalaca. Sin embargo, todavía falta la decisión política y vencer muchos obstáculos e intereses creados y burocracia. Imagen obtenida de www.caretas.com.pe

\section{Moción aprobada en el Congreso:}

02. De los congresistas Aita Campodónico y Flores Aráoz Esparza, del Grupo Parlamentario Unidad Nacional; Negreiros Criado, Gasco Bravo y Armas Vela, de la Célula Parlamentaria Aprista, mediante la cual proponen que el Congreso de la República "se pronuncie por la prioridad de que el Ministerio de Transportes, Comunicaciones, Vivienda y Construcción tome acciones urgentes para dar trámite a la ejecución del Proyecto Eco Callao, y que OSITRRAN se responsabilice de velar por las condiciones contractuales en coordinación con las empresas inversionistas y la 
Empresa Nacional de Puertos S.A., teniendo en cuenta que este pedido se cumpla en un plazo máximo de 60 días hábiles con el fin de salvaguardar en el más breve plazo posible las vidas de nuestros niños y la población en general de la Provincia Constitucional del Callao". Moción Nº 496 (17 -10-2001)

Nota de Redacción: Ya han pasado los seis meses indicados; sin embargo, todo parece haber sido solo una flor en el ojal.

\section{Fuentes}

Carolina Isabel Guerra - "Plomo... Peligro Inminente". http://oliva.ulima.edu.pe/pbguerra/

Museo Sardo de Antropología y Etnografía (Cagliari - Italia) $\underline{\text { http://www.unica.it/ museoae/proto3.html }}$

La Galería de Van Gogh. http://www.vangoghgallery.com/international/spanish/

Dirección General de Salud Ambiental - DIGESA (Perú). http://www.digesa.gob.pe

Consejo Nacional del Ambiente - CONAM (Perú). http://www.conam.gob.pe

Diario Gestión (Perú). http://www.gestion.com.pe

Diario La Crónica de Hoy (Saltillo - $\quad$ México). http://www.webcom.com.mx/cronica/1999/may/18/med03.html

Ministerio de Salud (Perú). http://www.minsa.gob.pe

R. Calmet\&Asociados. Callao (Perú). http://www.callao.org/plomo

Centro de Información y Control Toxicológico - CICOTOX (Perú). http://www.unmsm.edu.pe/farmacia/cicotox.htm 
Ministerio de Energía y Minas (Perú). http://www.mem.gob.pe

Instituto Nacional de Estadísticas (Perú). http://www.inei.gob.pe

Waste Magazine (España). http://www.ideal.es/waste/Indice.html

Centro Nacional de Salud Ambiental CDC (EEUU).

http://www.cdc.gov/nceh/globalhealth/spanish/Priorities/lead.htm

Portal sobre Arte \& Historia (España). http://www.artehistoria.com

Centro de Salud Ocupacional Alice Hamilton (Alice Hamilton Occupational Health Center). http://www.alicehamilton.org/spanish/sindex.html

Vida Sana, tu web de salud. http://www.550m.com/usuarios/vidasana/Index.html 